\title{
Botanikai élet a dualizmus kori Magyarországon (1867-1918) II. Kulturális és tudományos intézmények
}

\author{
PIFKÓ Dániel \\ Magyar Természettudományi Múzeum, Növénytár, \\ 1087 Budapest, Könyves Kálmán krt.40.; e-mail: pifko.daniel@nhmus.hu
}

Elfogadva: 2019. május 6.

Kulcsszavak: agrárintézmény, botanikatörténet, flórakutatás, herbárium, múzeum.

Összefoglalás: A dualizmus előtt csak egyetlen kulturális intézményben, a Nemzeti Múzeumban dolgozott „f́̋állású” botanikus, növénytannal foglalkozó tudományos intézetek pedig nem működtek a magyar állam területén. A dualizmus kezdeti időszakában látványosan fejlődött a botanika oktatása, ez a fejlődés az egész korszakban folytatódott. A gyorsan fejlődő felsőoktatási intézményekben egyre több olyan jól képzett szakember végzett, aki az 1880-as évektől létrehozott új kulturális és tudományos intézményekben helyezkedett el mint botanikus. Ezek az intézmények a korszak utolsó időszakában jelentősen fejlődtek, és az első világháború előtt már 25-30 botanikust alkalmaztak.

A kiegyezés után a Nemzeti Múzeum keretein belül létrejött az önálló Növénytani Osztály, ahol kezdetben egy botanikusnak volt állása, de a korszak végén már hat egyetemet végzett szakember dolgozott az osztályon, amely így a flórakutatás egyik legfontosabb hazai intézménye lett.

Vidéken a lokálpatrióta egyesületek olyan múzeumokat alapítottak, melyek természettudományos gyüjteménnyel is rendelkeztek. Ezek a múzeumok 1897-ben állami felügyelet alá kerültek, ami biztosította a hosszú távú fennmaradásukat. Számos vidéki múzeum növénygyüjteményének a gyarapításában vagy kezelésében helyi tanárok, papok, orvosok vagy más foglalkozású amatőr botanikusok is részt vettek, így ezeknek az intézményeknek is jelentős szerepük volt a hazai flórakutatásban. A mezőgazdasági, szőlészeti és erdészeti tudományos intézetek az 1880-as évektől kezdve jöttek létre, és elsősorban vidéki vagy fővárosi oktatási intézmények mellett müködtek. A korszak utolsó két évtizedében számos, mezőgazdasággal foglalkozó intézményt Budapestre költöztettek az oktatási intézményektől függetlenül működő Ampelológiai Intézet mellé, mivel azt tervezték, hogy egy központi Országos Mezőgazdasági és Szőlészeti Intézetet hoznak létre. Az agrár- és erdészeti kutatóintézetek eltérő intenzitással kapcsolódtak be a flórakutatásba, aminek egyik legfontosabb hazai központja a budapesti Vetőmagvizsgáló Állomás volt, melyet Degen Árpád vezetett.

\section{Bevezetés}

1918-ban véget ért a dualizmus időszaka, ennek százéves évfordulójára a szerző két cikket jelentetett meg (PIFKó 2018a, b), melyben a korszak botanikai életével, illetve a bekövetkezett változások hatásával foglalkozott. A változások eredményeként nemcsak az oktatás fejlődött a korszakban, hanem új tudományos és kulturális intézmények is létrejöttek. Jelen tanulmány ezen intézmények müködésével és az ezekben foglalkoztatott botanikusok életével, munkás- 
ságával foglalkozik. A cikksorozat első részéhez (Pıғ Kó 2018a) hasonlóan elsősorban azt vizsgálja a tanulmány, hogy az intézmények fejlődése milyen hatást gyakorolt a flórakutatásra, emiatt azoknak a kulturális és tudományos intézményeknek a müködését tekinti át, amelyek szorosabb kapcsolatban álltak a hazai flórakutatással, így az állami fenntartású vagy államilag támogatott múzeumok, agrár, szőlészeti és erdészeti tudományos intézetek munkáját tárgyalja részletesebben. A dualizmus kori egyesületi életet és a Magyar Tudományos Akadémia müködését a sorozat harmadik része mutatja be.

A dualizmus korának intézményeivel már korábban is foglalkozott néhány munka (Goмвосz 1936, Somlyay 1999), a múzeumok, kutatóintézetek történetéről pedig különböző évfordulók alkalmával születtek feldolgozások (FILarszky 1902, Augusztin 1922, Degen 1922, Dicenty 1922, Kern 1922, TAKÁcs 1967, Fekete és Kováts 1974, Buczkó 1995). A korszak legjelentősebb botanikusairól önálló cikkekben vagy különböző lexikonokban jelentek meg életrajzok. Jelen tanulmányban, felhasználva a korábbi szerzők eredményeit, áttekintést szeretnénk nyújtani a korszakban működő olyan intézményekről, melyek hatással voltak a hazai flórakutatásra, bemutatva a korszak legjelentősebb botanikusait is.

\section{Anyag és módszer}

A tanulmányban felhasználtunk botanikatörténeti munkákat, életrajzokat, lexikonokat és különbözö intézmények történetét bemutató müveket. Fontos forrás volt Magyarország tiszti cím- és névtára, amely 1873-tól minden évben megjelent, és tartalmazta az állami intézményekben dolgozó hivatalnokok névsorát, illetve a Budapesti Czim- és Lakjegyzék, amely 1880-tól jelent meg rendszeresen; az ezekben szereplő adatokat az életrajzok és az intézmények történetét és működését bemutató munkák alapján pontosítottuk. Emellett felhasználtuk a korszak digitálisan elérhető sajtóját is. A Kisérletügyi Közlemények számaiban megjelent ismertetők is fontos forrásul szolgáltak a jelen tanulmányhoz: ezek az egyes intézetek történetét, működését és személyi állományát tárgyalták.

A tanulmányban számos olyan település neve szerepel, mely ma nem Magyarország területén található, de magyar neve is van. Ilyen esetekben a magyar név szerepel a szövegben, de ahol szükségesnek éreztük, zárójelben annak az országnak a hivatalos nyelvén is feltüntettük a település nevét, ahová az jelenleg tartozik. A tanulmányban szerepelnek olyan kárpát-medencei botanikusok is, akik vállaltan nem magyar nemzetiségüek voltak. Ezeknek a személyeknek a neve is magyar alakjukkal szerepelnek a szövegben, mivel a korszak magyar nyelvủ irodalmában ezt a változatot használták, de ahol indokolt, zárójelben feltüntettük a nemzetiségnek megfelelő névalakot is. 
Az intézmények nevét a cikkben rövidített formában szerepeltetjük, hasonlóan, mint Pı Fó (2018a) korábbi munkájában: Szőlészeti Kísérleti Állomás és Ampelológiai Intézet: Ampelológiai Intézet; Budapesti Magyar Királyi Tudományegyetem: Budapesti Egyetem; Királyi József Műegyetem: Műegyetem; Magyar Királyi Ferenc József Tudományegyetem: Kolozsvári Egyetem; Magyar Királyi Mezőgazdasági Múzeum: Mezőgazdasági Múzeum; Magyar Nemzeti Múzeum: Nemzeti Múzeum; Magyar Királyi Vetőmagvizsgáló Állomás: Vetőmagvizsgáló Állomás.

A tanulmányban szereplő fotók a Magyar Természettudományi Múzeum könyvtárának gyüjteményéből származnak.

\section{Növénygyüjtemények, múzeumok a dualizmus időszakában}

A dualizmus időszakában jelentősen nőtt a természettudományos magángyüjtemények száma. A 19. században a hivatásos botanikusok mellett számos orvos, pap, tanár, erdész és más természettudományos érdeklődésű ember gyüjtött növényeket. A magángyüjtemények idővel állami, egyházi vagy egyesületi fenntartású intézményekbe, elsősorban múzeumokba vagy iskolákba kerültek. Ezek a herbáriumok dokumentálták a botanikusok tudományos munkáját és reprezentálták egy-egy terület flóráját is, így nélkülözhetetlen alapot biztosítottak a rendszertani, florisztikai és növényföldrajzi kutatások számára.

Egy 1902-1903-as felmérés alapján 286 természettudományos gyüjtemény volt az országban, melyek különböző intézmények tulajdonában voltak, egyházi és állami gimnáziumokban, felsőbb iskolákban, egyetemeken, akadémiákon, vagy olyan múzeumokban, melyeket egyesületek hoztak létre és tartottak fenn az állam támogatásával. Ezek közül az intézmények közül 130 rendelkezett legalább 100 darabos herbáriummal, körülbelül 80-ban pedig több mint 800 példányt őriztek. A nagyobb gyüjtemények általában jelentősebb botanikusok anyagával is rendelkeztek. Néhány helyen, elsősorban rangos gimnáziumokban, tízezer felett volt a herbáriumi példányok száma (ANONYMUs 1904).

Mivel a dualizmus kori intézmények fejlesztése elsősorban a Nemzeti Múzeum Növénytani Osztályát és a helyi lokálpatrióta egyletek múzeumait érintette, így az alábbiakban ezekkel foglalkozunk részletesebben, illetve az ebben az időszakban alakult Mezőgazdasági Múzeummal, amelynek szintén volt botanikai gyűjteménye.

\section{A Magyar Nemzeti Múzeum Növénytani Osztálya}

Trefort Ágoston (1817-1888) európai műveltségű, haladó gondolkozású kultuszminiszter volt, aki az oktatás mellett a kulturális intézmények fejlesztését is támogatta. Pulszky Ferenc (1814-1897) pedig, aki a korszak első felében igazgatta a Nemzeti Múzeumot, nemzetközi tapasztalatokkal és politikai befolyás- 
sal is rendelkezett, ennek is köszönhető, hogy a dualizmus időszakában jelentősen fejlödött az ország egyik legfontosabb kulturális, tudományos intézménye, a Nemzeti Múzeum, ahol nőtt az intézmény állami támogatása, növekedett a dolgozók létszáma, és a gyüjtemények elhelyezési körülményei is javultak (FEJös 1965, BoDó 2016). Ennek a fejlődésnek köszönhető, hogy a korszak végére a múzeum Növénytani Osztálya lett az egyik legfontosabb központja a hazai és a balkáni flórakutatásnak.

Elözmények - A Nemzeti Múzeumot 1802-ben alapította Széchényi Ferenc, ennek az intézménynek a keretein belül állították fel a Természettárat 1810-ben, melyben a növénygyüjtemény is helyet kapott. A tárat egy természettudós vezette, a munkáját pedig általában egy vagy két segédőr segítette, akik szintén egyetemet végzett szakalkalmazottak voltak. Botanikusok közül Sadler József (1791-1849; segédőr, őr: 1820-1849) és Kováts Gyula (1815-1873; segédőr, őr: 1850-1865) vezették a Természettárat. A tár segédőre, majd őre volt Frivaldszky Imre (1799-1870; segédőr, őr: 1822-1851), aki zoológiai munkája mellett foglalkozott a Balkán növényvilágával is (FILARSZKY 1902).

$A z$ intézmény fejlödése - Pulszky Ferencet 1869-ben nevezték ki a Nemzeti Múzeum igazgatójának, működési ideje alatt az intézmény jelentősen fejlődött. A múzeum keretei között nyolc önálló egységet alakítottak ki 1870-től. Ezek egyike a Növénytani Osztály volt, melynek 1870 elött az Ásványtári Osztállyal közös igazgatója volt. Az önálló Növénytani Osztály létrejöttét Haynald Lajos (18161891 ) is támogatta (JANKA 1880, Bodó 2016).

A Növénytani Osztály anyaga az 1880-as és 1890 -es években nagy magángyüjteményekkel gyarapodott: 1883-ban Tauscher Gyula (1833-1882) herbáriuma és Hazslinszky Frigyes (1818-1896) mohagyüjteménye, 1892-ben Haynald Lajos és Vágner Lajos (1815-1888) herbáriuma, 1893-ban pedig Résely Mihály (1813-1892) herbáriuma is a múzeumba került. 1895-ben 400 000-re becsülték az intézményben található példányok számát. A gyüjtemény a dualizmus időszakának utolsó harmadában is jelentősen gyarapodott: 1910-ben Simonkai Lajos (1851-1910), 1912-ben Szépligeti Győző (1855-1915) és Csató János (18331913), 1916-ban Waisbecker Antal (1835-1916) anyaga került a múzeumba. A gyarapodás miatt a növénygyüjtemény elhelyezése többször is változott a korszakban, a Magyar Tudományos Akadémia épületének második emeletére 1905ben került, ahol 45 éven keresztül működött a Növénytani Osztály (FILARSZKY 1902, FeKeTe és Kováts 1974, BuCzKó 1995).

A gyűjtemény gyarapodásával nőtt a kezeléssel járó munka is. Az 1880-as években egy szolga és napidíjasok segítették a munkát, 1896-tól már egy segédőr is dolgozott a vezető mellett, 1905-től pedig két napidíjast alkalmaztak a Növénytani Osztályon. A napidíjasokat idővel segédőrnek nevezték ki, 1912-től három, 1918-tól pedig négy muzeológusi állás volt a vezető mellett, de már ebben 
az időben itt dolgozott Timkó György is, mint napidíjas (1. ábra), így a legfontosabb növénycsoportok gyüjteményeit már ebben az időben megfelelő specialista felügyelte (FILARSZKY 1902, BUCZKó 1995).

A múzeum fejlődése lehetővé tette, hogy természettudományos folyóiratot indítson az intézmény. A Magyar Nemzeti Múzeum természetrajzi osztályainak folyóirata, a Természetrajzi Füzetek 1877-től jelent meg 25 éven át, majd 1902től Annales historico-naturales Musei nationalis hungarici lett a múzeumi kiadvány neve. A Növénytani Osztály botanikusain kívül mások is publikáltak a lapban, a korszak két meghatározó flórakutatójának, Simonkai Lajosnak és Borbás Vincének (1844-1905) is számos cikke jelent meg a folyóiratban. Az 1900-as években Hollós (Schwartzkopf) László (1859-1940), Európa-szerte ismert gombászunk is rendszeresen publikálta itt az eredményeit, elsősorban Kecskemét környékének gombáiról.

Vezetök - Janka Viktor (1837-1890; 2. ábra) 12 éves korától szenvedélyesen gyüjtött növényeket, ennek ellenére mint katona kezdte meg a pályáját. 1869ben felajánlottak neki egy állást Oroszországban, ahol lehetősége lett volna az ország kevéssé kutatott területein botanizálni, és bár nemet mondott, félő volt, hogy előbb-utóbb külföldre távozik (ANONYMUs 1869). Szerencsésen alakult, hogy ebben az időszakban, 1870-ben választották szét három osztályra a Nemzeti Múzeum Természettárát, és az újonnan létrehozott Növénytani Osztály vezetésével Janka Viktort bízták meg. Kinevezését a politikai körökben befolyásos Haynald Lajos is támogatta, akivel Janka baráti viszonyban volt. Janka Viktor Európa-hírű botanikus volt, aki a Kárpát-medencén kívül a Balkán területén is kutatott. Bár a Magyar Tudományos Akadémia anyagilag támogatta útjait, és

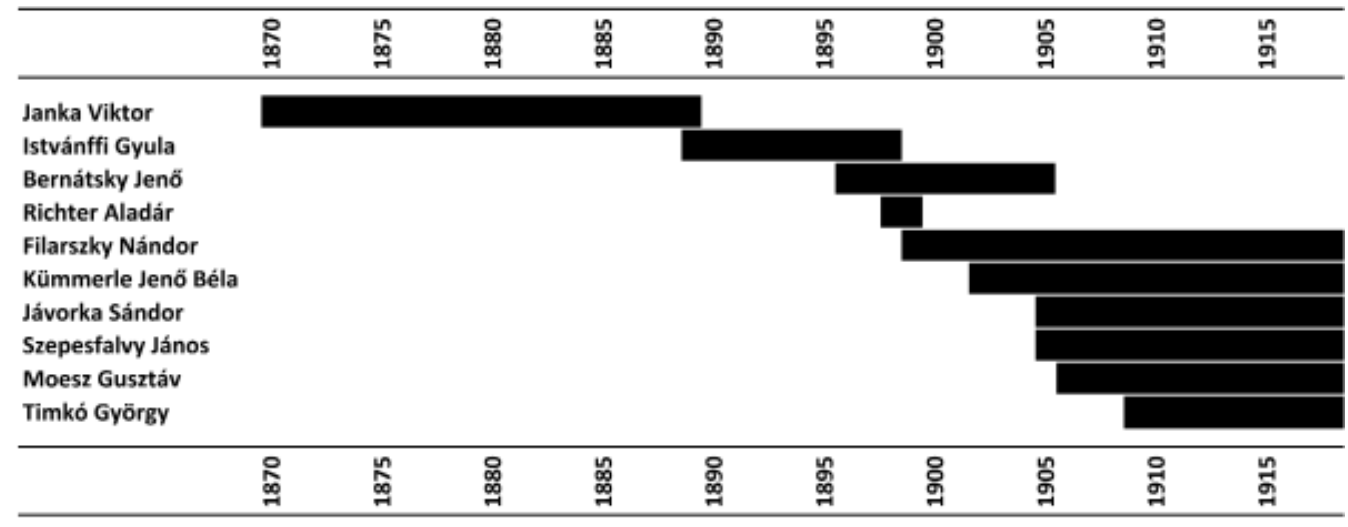

1. ábra. A Magyar Nemzeti Múzeum Növénytani Osztályán dolgozó szakalkalmazottak szolgálati ideje a dualizmus időszakában (1870-1918).

Fig. 1. Service periods of museologists in the Botanical Department of the Hungarian National Museum during the dualistic era (1870-1918). 


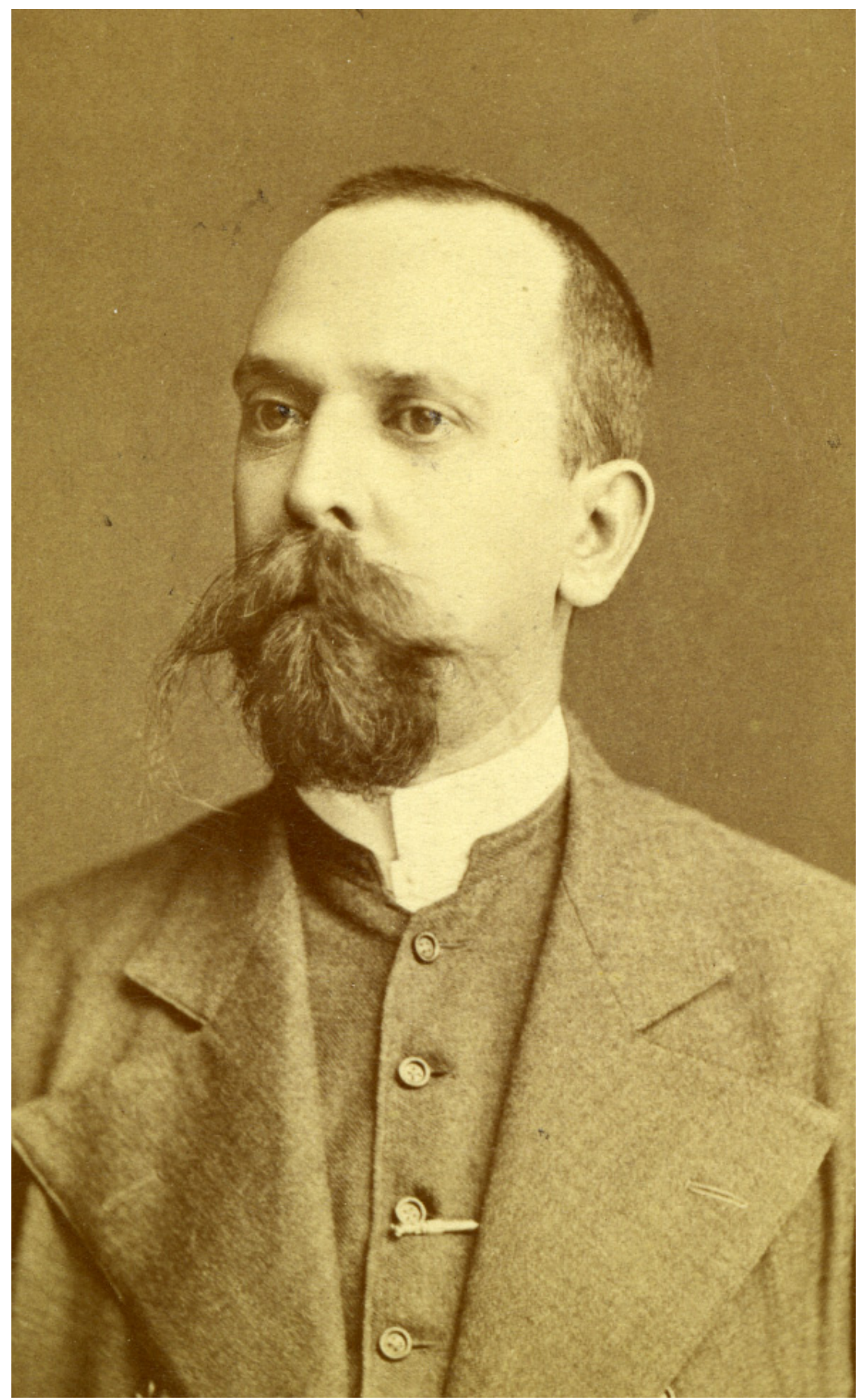

2. ábra. Janka Viktor, a Magyar Nemzeti Múzeum Növénytani Osztályának első vezetője.

Fig. 2. Viktor Janka, the first director of the Botanical Department of the Hungarian National Museum. 
az akadémián működő Matematika és Természettudományi Bizottságba is beválasztották 1876-ban, a magyar akadémiai tagságot háromszori jelölés (1885, 1886, 1887) ellenére sem kapta meg (SZINNYEI 1897).

Istvánffi (Schaarschmidt) Gyula (1860-1930) Janka Viktor nyugdíjazása után, 1889-ben vette át a Növénytani Osztály irányítását. Müködése alatt jelentős gyüjteményekkel gyarapodott az intézmény, többek között Haynald Lajos hatalmas herbáriumával. Istvánffi múzeumi éveiben kölcsönözte ki a leideni könyvtárból a Clusius-Codex-et, amely azokat a gombaakvarelleket tartalmazta, melyek akkor készültek, amikor Carolus Clusius (1526-1609) Batthyány Boldizsár (1542-1590) támogatásával bejárta a Kárpát-medence nyugati részét, és az itt élő edényes növényeket és gombákat vizsgálta. Istvánffi lemásolta és közreadta a Clusius-Codex ábráit, illetve számos előadásban és publikációban számolt be Clusius munkásságáról, aki a Kárpát-medence első jelentős flórakutatója volt (Degen 1932, AumüLler és JeANPLong 1983). Istvánffit Kanitz Ágost (18431896) halála után egyetemi tanárnak nevezték ki a Kolozsvári Egyetemre, így 1898-ban elhagyta a múzeumot. Öt Richter Aladár követte a Növénytani Osztály élén (1868-1927; őr: 1898-1899), aki alig több mint fél évig vezette az osztályt, mivel ő is Kolozsvárra távozott Istvánffi helyére, aki visszatért Budapestre, hogy az újonnan létrehozott Ampelológiai Intézetet vezesse (FILARSZ KY 1902).

Filarszky Nándor, aki a virágos növények mellett elsősorban moszatokkal és gombákkal foglalkozott, 1899-ben került a Növénytani Osztály élére. Múzeumi évei alatt a hivatali munkáját tekintette elsődlegesnek. A Növénytani Osztály anyagainak rendezésében, a gyűjtemények költöztetésében, a jelentős gyarapodás feldolgozásában, és a szakfelügyelői munkájában ez a hivatali fegyelem segítette. Múzeumi munkája mellett tanított a Budapesti Egyetemen és az Eötvös Collegiumban. Egyetemi kapcsolatai lehetővé tették, hogy a múzeum létszámbővítése során a legalkalmasabb embereket válassza ki. Az ő idejében került megfelelő szakember a legjelentősebb kriptogám gyüjtemények (moha-, gomba-, zuzmógyűjtemény) élére. Oktatói tevékenységéhez kapcsolódott egyik fő műve, egy növénymorfológia tankönyv elkészítése is. Tudományos munkája a hivatali idejében háttérbe szorult, így a nemzetközi hírü Chara monográfiáját csak azután készítette el, miután nyugdíjba vonult. Borbással való rossz viszonyának tudható be, hogy annak gyüjteménye halála után nem a múzeumba került, hanem a Budapesti Egyetemre (MoEsz 1943).

Dijnokok (napidijasok), segédek, segédörök, örök (muzeológusok) - A múzeum az 1880-as években már olyan fiatal napidíjasokat alkalmazott, akiknek a többsége egyetemi tanulmányai mellett dolgozott a Növénytani Osztályon, de emellett a gyüjtemény gyarapításában is részt vett. Hermann Gábor az 1880-as évek első felében segítette az osztály munkáját, mint napidíjas. Az ő életrajzi adatait nem ismerjük, de ebben az időszakban elsősorban Budapest környékén gyüjtött 
növényeket a múzeum számára, a legfontosabb eredményeit pedig publikálta is. Perlaky Gábor (1871-?) szintén napidíjasként vett részt Vágner Lajos gyüjteményének feldolgozásában (PIf Kó et al. 2015). Perlaky, aki a Budapesti Egyetemen végzett az 1890-es években, föleg a föváros környékén botanizált, herbáriumát a Magyar Természettudományi Múzeum őrzi. Francé Rezső (1874-1943) a müegyetemi tanulmányai mellett szintén napidíjasként dolgozott a Növénytani Osztályon 1892-ben (FILARSZKY 1902).

Bernátsky Jenőt (1873-1945) 1896-tól alkalmazták díjnokként, majd még ebben az évben segédnek nevezték ki, mely állandó fizetést biztosított számára. Bernátsky 1905-ig dolgozott a múzeumban, innen az Istvánffi Gyula vezette Ampelológiai Intézetbe távozott. Múzeumi évei alatt elsősorban a Nyírség és Versec környékének flórájával foglalkozott, de növényanatómiai és mikológiai tanulmányokat is folytatott, gyüjteményét ma a Növénytár őrzi (JÁvor KA 1957).

A korszak második felében lehetőség volt arra, hogy a Növénytani Osztály állandó munkatársakat alkalmazzon, akik idővel egy-egy gyüjtemény vezetőjeként a rájuk bízott növénycsoportok legfontosabb hazai szakértői lettek. Kümmerle Jenő Béla (1876-1931) az V. kerületi fögimnáziumban végzett, ahol Fialowski Lajos (1846-1909), a botanikatörténet jeles kutatója is tanította őt, de a botanikát Mendlik Ferenc (1838-1902) matematikatanár szerettette meg vele. 1898-tól Mágócsy-Dietz Sándor tanársegéde volt, majd 1902-től élete végéig a múzeumban dolgozott. Virágos és virágtalan növényekkel is foglalkozott, de fö kutatási témája a harasztok voltak. Magyarországi gyüjtőútjai mellett elsősorban a Velebiten kutatott, de botanizált Albánia és Macedónia területén is. Horvátországi kutatásait segítette, hogy pályája kezdetén Degen Árpád herbáriumát is tanulmányozhatta. Az egyesületi életben is jelentős szerepet játszott, 1904 és 1906 között a Növénytani Szakosztály jegyzője volt, és ő állította össze 1905-től 1929ig a Botanikai Közlemények „Növénytani Repertorium” rovatát is (MoEsz 1933).

Jávorka Sándor (1883-1961), a 20. század egyik legjelentősebb magyar botanikusa 1905-ben került a Növénytani Osztályhoz. Jávorka élete végéig hü maradt a múzeumhoz, ahol nyugdíj után is dolgozott. A Kárpát-medence flóráján kívül az albán flórát is tanulmányozta az első világháború idején. Jávorka végezte el azt a munkát, amelyet a kárpát-medencei flórakutatók az egész dualizmus időszakában fontos feladatuknak tekintettek. Felhasználva a múzeum gazdag herbáriumát és könyvtárát, saját és mások tereptapasztalatait, és feldolgozva Kitaibel Pál hagyatékát, megírta a Magyar Flórá-t, amely a Kárpát-medence edényes flórájának határozó könyve (JÁvORKA 1925). Ennek a kiegészítéseként jelent meg 1926 és 1934 között füzetenként, majd 1934-ben egy kötetben is $A$ magyar flóra képekben, vagy más néven az Iconographia, amelybe Csapody Vera (1890-1985) készítette a rajzokat a Kárpát-medencében előforduló növényekről (JÁvoRKA és CSAPODY 1934). Jávorka a hazai flórakutatás egyik központi alakja volt, jó kap- 
csolatot ápolt a hazai flórakutatókkal, gyakran segítette őket a növények meghatározásában, emellett nemzetközi kapcsolatai is voltak. Jávorka annak ellenére lett a magyar botanika egyik legnagyobb hatású kutatója, hogy az egyetemi oktatásba nem kapcsolódott be aktívan (ZólYomi 1961).

Az edényesnövény-gyüjtemények mellett gyors ütemben gyarapodtak a kriptogám gyüjtemények is, ezért szükség volt arra, hogy ezeket a speciális tudást igénylő herbáriumokat is a megfelelő szakemberek gondozzák, ezért a dualizmus utolsó harmadában számos kriptogám specialista kapott állást a múzeumban. A korszak végére az összes jelentős gyüjteményt jól képzett botanikus felügyelte (3. ábra).

Szepesfalvy (Szurák) János (1882-1959) Jávorka Sándorral egy időben, 1905-ben került az intézménybe, ahol nyugdíjazásáig, 1943-ig dolgozott. Ö volt a különválasztott mohagyüjtemény első vezetője. Az első világháború előtt intenzíven gyüjtött az ország különböző részein azzal a céllal, hogy megírja Magyarország mohaflóráját. A háború idején katonai szolgálatot teljesített. A két világháború között is aktívan kapcsolódott be a hazai botanikai életbe, ebben az időszakban publikálta a múzeum lapjában fő művét, mely Budapest és környékének mohaflóráját dolgozta fel (SomLYAY 1997).

1911. Th. tel. Siramkowion

1. Kümmesle J. B.

2. Filarsing. N.

3. Moes? $y$.

4. Timikó $\sigma_{\text {. }}$

5. Diontat.

6. Seurakj.
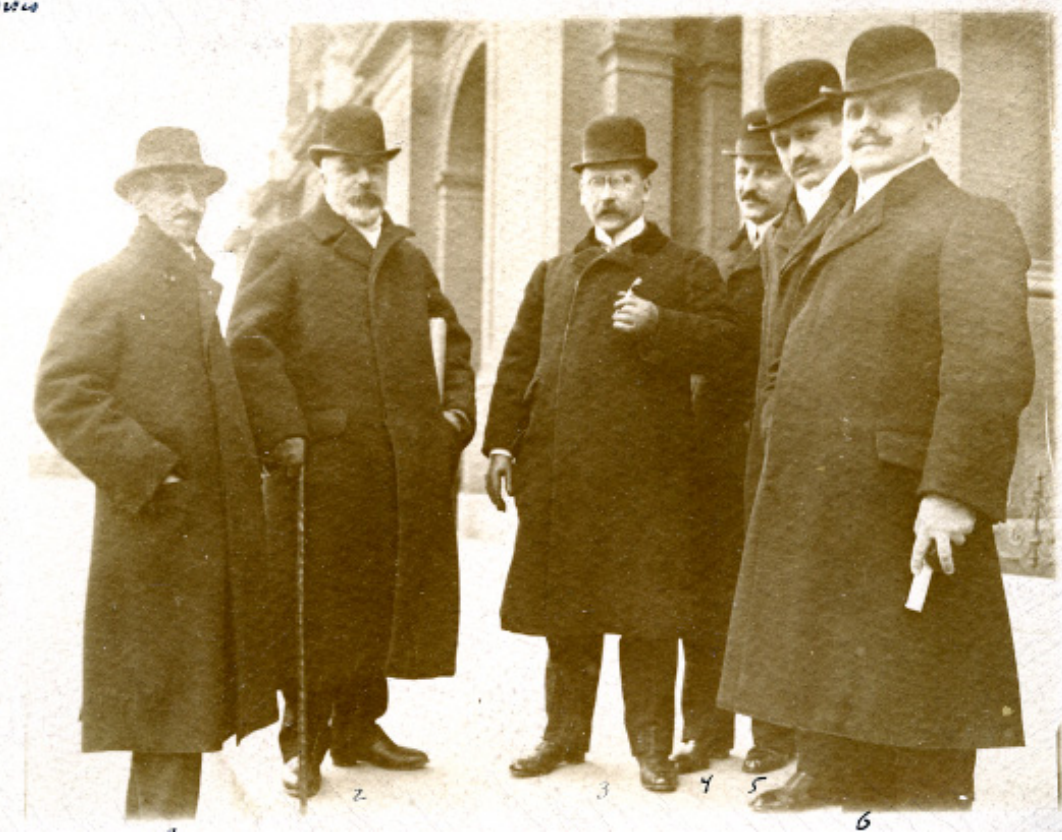

3. ábra. Együtt a Magyar Nemzeti Múzeum Növénytani Osztálya (1911). Balról: Kümmerle Jenő Béla, Filarszky Nándor, Moesz Gusztáv, Timkó György, Jávorka Sándor, Szepesfalvy (Szurák) János. (Fotó: Sztankovics Rezső).

Fig 3. Botanists of the Botanical Department of the National Museum in 1911: Jenő Béla Kümmerle, Nándor Filarszky, Gusztáv Moesz, Sándor Jávorka, János (Szurák) Szepesfalvy (photo: Rezső Sztankovics). 
Moesz Gusztáv (1873-1946) 1895 és 1899 között Krenner József(1839-1920) tanársegéde volt a Budapesti Egyetem ásvány- és kőzettani tanszékén, utána pedig a brassói főreáliskolában tanított természetrajzot. 1906-ban került a Nemzeti Múzeum Növénytani Osztályához. Bár fiatalon még elsősorban virágos növényekkel és algákkal foglalkozott, Filarszky a múzeum gombagyüjteményének a rendezését bízta rá, így érdeklődése a mikológia irányába fordult. Nemzetközi szinten elismert gombász volt, aki mintegy 160 gombafajt írt le. Múzeumi munkája mellett, tanított a Paedagogiumban, amely a tanítóképzés központi intézmény volt, 1915-től pedig a mikológia egyetemi magántanára lett a Budapesti Egyetemen. Aktívan részt vett az egyesületi életben is, ő volt a Növénytani Szakosztály jegyzője 1908 és 1913 között. A két világháború között egyike a legjelentősebb hazai botanikusoknak, a Növénytani Szakosztály elnökének is megválasztották, és Filarszky nyugdíjazása után a Növénytárat is ő igazgatta (Boros 1958).

Timkó György (1881-1945) a zuzmógyüjtemény első vezetője, 1902-től a Magyar Nemzeti Múzeum Néprajzi Osztályán volt gyakornok, majd 1909-től a Nemzeti Múzeum Növénytani Osztályán az önálló zuzmógyűjtemény kialakításával bízták meg. Hazai és nemzetközi gyűjtéseinek és cserekapcsolatainak köszönhető, hogy a múzeum zuzmógyüjteménye jelentősen gyarapodott az időszakban. Timkó György pályája hosszantartó betegsége miatt nem teljesedhetett ki (SZINNYEi 1914, Boros 1947).

\section{Vidéki múzeumok}

A dualizmus második felében számos egyesületi vagy városi fenntartású vidéki múzeumot hoztak létre. Ezek sok esetben növénygyüjteménnyel is rendelkeztek, melyek elsősorban a helyi flórát reprezentálták. Számos, vidéken dolgozó botanikus munkássága kapcsolódott ezekhez a múzeumokhoz.

Elözmény - A dualizmus előtt csak legjelentősebb városainkban voltak olyan múzeumok, melyeket egyesületek tartottak fenn, és természettudományi gyüjteménnyel rendelkeztek. Igazán jelentős növénygyüjteménye csak az Erdélyi Múzeumi Egyletnek volt, mely hivatalosan 1860-ban kezdte meg működését az Erdélyi Királyi Gubernium központjában, Kolozsváron. Ez a herbárium több mint 52 ezer példányból állt, nem sokkal azután, hogy a Kolozsvári Egyetem 1872-ben létrejött, és átvette a herbárium kezelését (KANITz 1874). A Pozsonyi Orvos-Természettudományos Egyesület 1856-ban alapított múzeumot, ahol már az első évben 680 edényes és 440 kriptogám növény volt. Bolla János (1806-1881) tanár, aki Pozsony környékének flóráját kutatta és mikológiával is foglalkozott, 142 példányt adományozott az intézménynek, ez a herbárium alapozta meg a pozsonyi múzeum növénygyüjteményét (FISCHER 1907). 
Az intézmények fejlődése - Az 1870-es évektől számos olyan vidéki, lokálpatrióta egyesületet alapítottak, melynek céljai között szerepelt a természeti értékek kutatása is. Ezek az egyesületek olyan múzeumokat hoztak létre, ahol a természettudományos gyüjtemények is helyet kaptak. A dualizmus első felében működő vidéki múzeumok természetrajzi gyüjteményeiről Csiki Ernőnek (1875-1954), a Nemzeti Múzeum entomológusának, igen kritikus véleménye volt: „A törvény életbelépése előtt [1897] a vidéki múzeumok ügye nagyon mostohán állott, sőt legtöbbje azóta alapíttatott, azóta működik. Úgy a régebbi, mint az újabb múzeumok természetrajzi gyüjteményei, kevés kivétellel, nagyon silányak voltak" (CsI KI 1907).

Wlassics Gyula (1852-1937) vallás- és közoktatásügyi miniszter 1897-es rendelete szabályozta a községi, felekezeti és egyesületi múzeumok és könyvtárak működését. A rendeletben a Múzeumok és Könyvtárak Országos Főfelügyeletét szakmai ellenőrzéssel és tanácsadással bízták meg, így azok a múzeumok is minisztériumi felügyelet alá kerültek, amelyeket egyesületek működtettek. Az érdemi munka 1901-től átkerült a főfelügyelettől a Múzeumok és Könyvtárak Országos Tanácsához. A Tanácsnak a botanikusok közül - 1903-tól az egész vizsgált korszakban - Filarszky Nándor volt a tagja (4. ábra). Az 1897-es rendelet állami szakfelügyeletet és támogatást biztosított a múzeumoknak, emellett a Tanács tanfolyamokat szervezett a vidéken dolgozó gyüjteménykezelőknek a Nemzeti Múzeum Növénytani Osztályán, melyeket az igazgató, Filarszky Nándor vezetett. Az állami szerepvállalás segített abban, hogy a vidéki múzeumokban őrzött növénygyüjtemények hosszú távon biztonságos elhelyezést nyerjenek (Fra KNói 1908, VoIT 1992, Sipos 2013, Bodó 2016).

CsıKI (1907) azt javasolta, hogy „... minden múzeum tekintse első feladatának a környék, a vármegye, vagy működési területének megfelelőleg, az illető országrész természeti kincseinek összegyüjtését. A vidéki múzeumok czélja elsősorban a közönséggel a környék természeti tárgyait megismertetni és pedig úgy, hogy annak figyelmét fölhívhassa azok fontosságára." Ennek a javaslatnak megfelelően számos tanár vagy más foglalkozású botanikus gyüjtött jelentős herbáriumot lakóhelye környékén, mely herbáriumokat a helyi múzeum számára ajánlották fel. Több olyan vidéki múzeum müködik ma is, melynek növénytani gyüjteményét ekkor alapozták meg.

Múzeumok, növénygyüjtemények - A korszakban készült felmérések alapján, számos vidéki múzeumban legfeljebb pár száz példányból állt a növénygyüjtemény. A Pécsi Városi Múzeumban 33 példányt (MIHALI K 1917), a kiskunfélegyházi Városi Múzeumban 80 példányt (MiHalı K 1916), a keszthelyi Balatoni Múzeumban 295 példányt, a zombori Bács-Bodrog Vármegyei Történelmi Társulat múzeumában pedig 517 példányt (MıнALı K 1916) őriztek. A Nagybányai Városi Múzeumnak a 


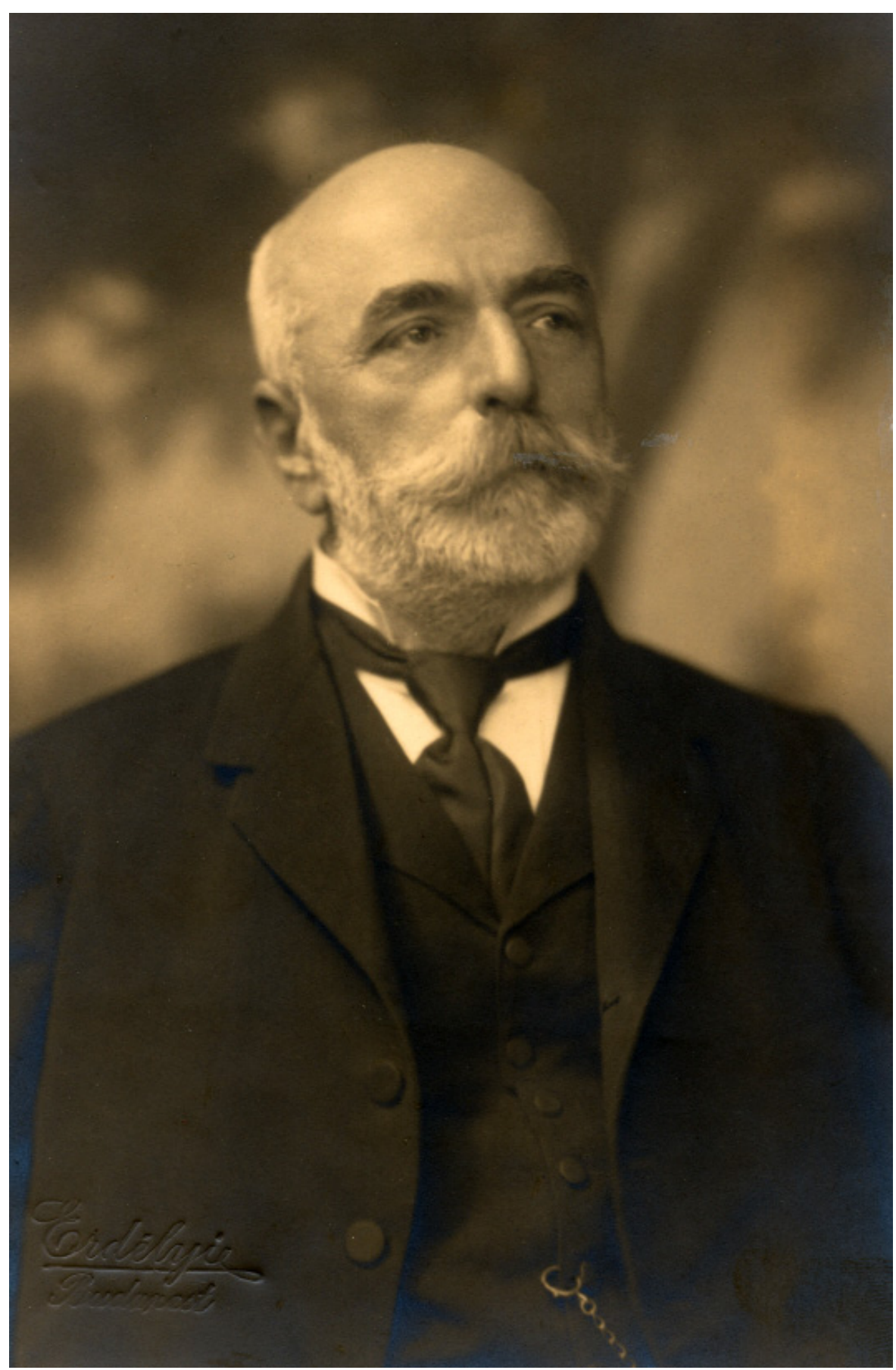

4. ábra. Filarszky Nándor, a Magyar Nemzeti Múzeum Növénytani Osztályának vezetője és a vidéki múzeumok felügyeletét ellátó tanács botanikus tagja.

Fig. 4. Nándor Filarszky, director of the Botanical Department of the Hungarian National Museum and botanical inspector of the provincial museums. 
rozsnyói származású Varga Sándor, a nagybányai állami főgimnázium tanára ajándékozott 211 herbáriumi példányt (WLASsics 1913, ANONYMUs 1942).

Nagyobb növénygyüjteménnyel rendelkezett a Veszprémmegyei Múzeum, ahol 1354 példányt őriztek (MiHalik 1916), a Pozsonyi Orvos-Természettudományos Egyesület múzeumában pedig 3732 példány volt (FEIGLER 1907, MiHALIK 1916).

Számos más vidéki múzeum szintén több mint ezer lapos herbáriummal rendelkezett, ezekben a gyüjteményekben jelentős botanikusok herbáriumát is őrizték. A temesvári Délmagyarországi Természettudományi Társulat múzeumában 1460 növénypéldány volt (MiH ALI K 1916), aminek számottevő részét, 1016 példányt Vuchetich Ferenc (1811-1889) ruszkabányai katolikus pap ajándékozta a társulatnak 1878-ban. Vuchetich herbáriuma elsősorban saját példányaiból állt, melyek többségét Krassó-Szörény vármegyében gyüjtötte, de emellett Pancic Józseftől (Josif Pančić, 1814-1888), Heuffel Jánostól (1800-1857) és Josef C. Ritter von Pittoni (1797-1878) grazi botanikustól is voltak példányai. Ezekkel a botanikusokkal csereviszonyban állt, illetve Panciccsal közösen is gyüjtött növényeket, mikor a neves szerb botanikus 1845-ben Ruszkabányán nevelösködött (KunN 1878, Kováts 1908). A Verseci Városi Múzeumban 1308 példányt őriztek, melynek egy részét a verseci származású Bernátsky Jenő adományozta az intézménynek (ALAPI 1911, MiHalik 1916).

A szombathelyi Vasvármegyei Kultur-Egyesület múzeumában 1912-ben 2340 herbáriumi példány volt. Ennek nagy részét (több mint 2000 példányt) Waisbecker Antal, Vas vármegye tisztiföorvosa, a megye egyik legjelentősebb botanikusa ajánlotta fel 1908-ban, a természetrajzi gyüjtemény létrehozásakor. Emellett Piers Vilmos (1838-1920) hivatásos katona is adományozott egy kisebb kriptogám gyüjteményt a múzeumnak (VIGH és BALOGH 2009).

Számos olyan múzeum volt a Felvidéken is, ahol jelentős botanikusok herbáriumát őrizték. A felkai Tátra Múzeum természetrajzi gyüjteményében 4661 herbáriumi példány volt, ebbe a Balázsfalváról származó Bartal Kornél (18811918), a szekszárdi fógimnázium tanára ajánlott föl egy 375 példányos herbáriumot, amelyet Lucsivna (Lučivná) környékén gyüjtött növényekből állított öszsze (MıHAlı K 1915). A poprádi Magyarországi Kárpátegyesület Múzeumának a növénygyüjteményében 4745 herbáriumi példányt őriztek. A munkácsi születésü Margittai Antal (1880-1939), aki elsősorban az Északkeleti-Kárpátok flóráját kutatta, 125 példányt, Győrffy István (1880-1959) pedig, aki, mielőtt a Kolozsvári Egyetem tanára lett, a lőcsei állami föreáliskolában tanított, 576 példányt ajándékozott a múzeumnak (Mi halı K 1915, 1916). A Trencsén Vármegyei Múzeumegyesület múzeumának növénygyüjteményét elsősorban az egyesület aktív tagjai gyarapították, köztük az elnök, Brancsik Károly (1842-1915) orvos, aki híres zoológus volt, de botanikai munkái is jelentek meg (KIss 2015). Az egyesület al- 
elnöke, Holuby József Lajos (Jozef L'udovít Holuby, 1836-1923) evangélikus lelkész, szintén adományozott példányokat a múzeumnak. Holuby főleg Pozsony, Nyitra, Trencsén és Árva vármegyék flóráját kutatta, és jelentős herbáriumi anyagot gyüjtött müködési területén, Nemes-Podhrágy (Szlovákia, Zemianske Podhradie) környékén. Az egyesület múzeuma összesen 8406 példányt tartalmazott (JANOvSZKY 1895, MiHALiK 1916).

Az ország egyik legfontosabb nemzetiségi múzeumának is jelentős növénygyüjteménye volt. A turócszentmártoni (Turčiansky Svätý Martin) Múzeumi Tót Társaság múzeumában őrizték Kmet́ András (Andrej Kmet', 1841-1908) szlovák nemzetiségű katolikus pap herbáriumát, amely 15000 virágos növényt és 18 fasciculus virágtalan növényt tartalmazott. Kmet Andrást, aki a Múzeumi Tót Társaság elnöke is volt, a Rosa nemzetség egyik hazai specialistájaként tartjuk számon, így gyüjteménye rendkívül gazdag volt rózsa példányokban is. Holuby József szintén adományozott példányokat a múzeumnak. Emellett Vraclav Vraný (1851-1929) gyüjteménye is a múzeum birtokába került, miután Vraný 1909-től a múzeum alkalmazásában állt. Petrikovich János (1846-1914) megyei járásorvos, szintén ajánlott föl herbáriumot a múzeum számára. Petrikovich, mint a múzeum őre, numizmatikával is foglalkozott, valamint elkészítette Kmet' András gombagyüjteményének jegyzékét is (SzINNYE 1 1905). Emellett florisztikai cikkei is jelentek meg a múzeum lapjában, a Sborník Museálnej Slovenskej Spoločnostiban (ANONYMus 1917, Bodó 2016).

Számos középiskolai tanár gyarapította a vidéki múzeumok herbáriumait, akik közül többen a természetrajzi gyüjteményt is felügyelték az intézményben. A szegedi múzeum növénytani gyüjteményét Feichtinger Sándor (1817-1907) esztergomi orvos körülbelül 4000 példányt tartalmazó herbáriuma alapozta meg, amelyet a "nagy szegedi árvíz” után, 1884-ben ajánlott fel Szeged városának. A gyüjteményt a szegedi piarista fögimnáziumba helyezték el, innen a századforduló környékén került a szegedi Városi Múzeumba. A gyűjteményt Lányi Béla (1879-1918) leánygimnáziumi tanár fejlesztette tovább, aki 1908-ban került az iskolába. Ö elsősorban Szeged környékén gyüjtött, herbáriuma több mint 3000 lapból állt. Lányi a Budapesti Egyetemen tanult, ahol nagy hatással voltak rá Degen Árpád előadásai, de számos más botanikussal is jó kapcsolatot ápolt. Még Szegedről való távozása előtt megírta Csongrád megye flóráját. A szegedi múzeum gyüjteményébe került a Királyhalmi Erdőőri Szakiskola és az ottani Erdészeti Kísérleti Állomás igazgatójának, Teodorovits Ferencnek (1861-1929) egy kisebb herbáriuma is. A szegedi gyüjteményben a korszak végén összesen 13706 herbáriumi példány volt (MiHALIK 1917, CsONGOR 1960, GASKó 2003).

Az 1899-ben alapított Borsod-Miskolci Közművelődési és Múzeumi-Egylet múzeumának Budai József (1850-1939) gimnáziumi tanár ajánlotta fel gazdag herbáriumát, mely több mint tízezer példányból állt. Ez alapozta meg az intéz- 
mény növénygyüjteményét. Budai, aki a Bükk hegység flórájának egyik legjelentősebb kutatója volt, a múzeum természetrajzi gyüjteményét is felügyelte, jó szakmai kapcsolatot tartott fenn Jávorka Sándorral, aki segítette a problémás taxonok meghatározásában. Budai a flórakutatás mellett pomológiával is foglalkozott, 1924-ben megalakította a város növénynemesítő intézetét és faiskoláját, ő maga is számos almafajtát nemesített (ANONYMUs 1912, BUDAI 1914, EGYED 1969).

Erdélyben több lelkes lokálpatrióta is ebben az időben kezdte el a flóra kutatását és a helyi múzeumok fejlesztését. A Gyulafehérváron müködő Alsófehérmegyei Történelmi, Régészeti és Természettudományi Egyesület múzeumát, melyben 1915-ben 4124 növénypéldány volt, Cserni Béla (1842-1916) vezette, aki baráti kapcsolatban volt Haynald Lajossal is. Cserni a helyi gimnáziumban tanított, amikor megírta Gyulafehérvár és vidékének flóráját (SZINNYEI 1893, Minalik 1916, Szabó 2016). Nagyenyeden a Bethlen Kollégium növénygyüjteménye a szabadságharcban elpusztult. Elekes Károlynak (1844-1922), az intézmény tanárának a munkája jelentős volt ennek pótlásában, és így 1915-ben már 8020 példányt őriztek az iskola múzeumában (Mı HALI K 1916, BA Kó 2013).

A sepsiszentgyörgyi Székely Nemzeti Múzeumnak Bibó József (1843-1914) barátosi tanító özvegye ajándékozta férje negyven éven át gyüjtött herbáriumát, amely elsősorban Háromszék flóráját reprezentálta, 913 határozott és 648 határozatlan példánnyal (MıнALıK 1915, Kocs 2015). László Kálmán (1900-1996) főgimnáziumi tanuló, a későbbi neves mikológus, és édesapja, László Ferenc (1873-1925), aki 1897-ben végzett a Kolozsvári Egyetemen és 1901-től volt a Székely Nemzeti Múzeum öre, 1915-ben 342 növénypéldányt adományozott a múzeumnak (MiHalik 1916, PÉTER 1925, PÁzMÁNy 1996).

\section{A Magyar Királyi Mezőgazdasági Múzeum}

A Mezőgazdasági Múzeumot a millenniumi ünnepségek után hozták létre. A múzeum fö célja az volt, hogy bemutassa a modern mezőgazdaság eredményeit. Számos botanikus segített összeállítani a kiállítást, illetve többen a múzeum gyüjteményét is gyarapították. A múzeumban jelentős herbáriumi anyagot is öriztek, illetve bemutattak, ennek ellenére az intézményben nem alkalmaztak botanikust a dualizmus időszakában.

Az intézmény fejlődése - Az Országos Magyar Gazdasági Egyesület székházában 1869-től működött egy kertészeti múzeum, ez később gazdasági múzeummá bővült. Ez volt Magyarországon az első olyan tartós kiállítás, amelynek a témája a hazai mezőgazdaság volt. Ez a civil támogatásból fenntartott múzeum 1891-ben szünt meg (TAKÁcs 1967).

Darányi Ignác (1849-1927) földművelésügyi miniszter 1896. június 20-án kiadott rendeletével létrejött az állami költségvetésből fenntartott országos Mezőgazdasági Múzeum. Darányi Ignác abból a célból alapította az intézményt „hogy 
az ország mezőgazdasági termelése és fejlődése állandó és modern múzeumban bemutattassék." 1897-ben nyitották meg a kiállítást, ahol elsősorban a budapesti Városligetben 1896-ban megrendezett Országos Millenniumi Kiállítás mezőgazdasági, vadászati és néprajzi anyagát mutatták be (TAKÁcs 1967, FüLÖP 2007).

A 20. század első éveiben a Városligetben épült fel a Mezőgazdasági Múzeum épülete, ahol az új kiállítást 1907-ben nyitották meg. A kiállítás egy jelentős része a Földművelésügyi Minisztérium hatáskörébe tartozó tudományos intézetek és kísérletügyi állomások munkáját mutatta be. Többek között a Vetőmagvizsgáló Állomások, a Növényélet- és Kórtani Állomás, az Ampelológiai Intézet, és az Erdészeti Kísérleti Állomások eredményeit ismerhette meg a nagyközönség. A kiállítás létrehozásában számos szakterület elismert kutatója vett részt. Linhart György (1844-1925), a Növényélet- és Kórtani Állomás vezetője, a növényi betegségek bemutatásáért volt felelős, Angyal Dezső (1852-1936), a budapesti Kertészeti Tanintézet igazgatója a kiállítás kertészeti részét állította össze. Emellett közreműködött Degen Árpád, a budapesti Vetőmagvizsgáló Állomás vezetője, Istvánffi Gyula, az Ampelológiai Intézet igazgatója, és Vadas Jenő (18571922), az Erdészeti Kísérleti Állomás vezetője is (ANONYmus 1907, GoRKA 1908).

A Mezőgazdasági Múzeumban számos növénygyüjteményt őriznek, melyek közül néhány feltehetőleg már a dualizmus időszakában az intézménybe került. Simonkai Lajos gyüjtéseiből egy körülbelül 2000 darabos herbárium a dualizmus éveiben már biztosan a múzeum birtokában volt. Számos, az első világháború vége előtt összeállított exsiccata sorozatból szintén őriznek fasciculusokat a múzeumban. Ezek közül Sadler József: A 'Magyar Plánták' száritott gyüjteménye, a Degen Árpád vezetésével összeállított Magyar füvek gyüjteménye és a Magyar sásfélék, szittyófélék, gyékényfélék és békabuzogányfélék gyüjteménye lehet a legjelentősebb. Szintén a múzeum birtokában van Teodorovits Ferencnek a Duna-Tisza közi futóhomok növényzetéből összeállított herbáriuma (KERÉNYI-NAGY 2018).

\section{Gazdasági, erdészeti és szőlészeti tudományos és kísérletügyi intézetek}

A dualizmus kezdeti időszakában jelentősen fejlődött az erdészeti, a kertészeti és az agrároktatás. A magyar állam felügyelete alá került a selmecbányai Bányászati és Erdészeti Akadémia és a magyaróvári (ma: Mosonmagyaróvár) Magyar Királyi Gazdasági Felsőbb Tanintézet is, melyek korábban az osztrák birodalom Bécsben működő minisztériumai alá taroztak. Emellett más vidéki városokban is létrehoztak gazdasági tanintézeteket: Debrecenben, Kassán, Keszthelyen, Kolozsváron (Pif Kó 2018a).

A mezőgazdaság fejlesztésének másik fontos eleme volt, hogy az iskolák mellett kutatóintézetek és kísérleti állomások létesültek; ilyen intézmények korábban nem működtek az állam területén. Ezek az intézetek a korszak második felében in- 
dultak gyors fejlődésnek. Ebben nagy szerepe volt Darányi Ignác földművelésügyi miniszternek, aki a hivatali idejében az agrároktatás és -kutatás fejlesztését is sikeresen támogatta. A korszak végére az agrárkutatások központja Magyaróvárról Budapestre került át, ahol jelentős számú kutató dolgozott az intézetekben.

A mezőgazdasági, szőlészeti és erdészeti tudományos és kísérletügyi intézeteknek az volt a feladata, hogy elősegítsék a hazai gazdaság fejlődését, emellett ezek az intézmények végezték a szakterületükön a nagyobb szaktudást és technikai hátteret igénylő vizsgálatokat is. A hazai flórakutatással a budapesti Vetőmagvizsgáló Állomás, a Növényélet- és Kórtani Állomás, az Ampelológiai Intézet, illetve az Erdészeti Kísérleti Állomás állt kapcsolatban. A Budapesti Egyetem Növénytani Intézetének több korábbi tanársegéde is a Vegyészeti és Élelmiszervizsgáló Intézetben helyezkedett el, de ennek az intézetnek a kutatásai nem kapcsolódtak szorosan a botanikához (PIFKó 2018a, b). Ezek az intézmények különböző mértékben kapcsolódtak be a hazai botanikai életbe és a flórakutatásba, legjelentősebb szerepe a budapesti Vetőmagvizsgáló Állomásnak volt.

A mezőgazdasági tudományos intézetek munkáját a Budapesten működő Mezőgazdasági Kísérletügyi Központi Bizottság felügyelte, melynek Degen Árpád (1866-1934) volt a botanikus tagja. A bizottság 1898-tól folyóiratot jelentetett meg Kisérletügyi Közlemények néven, melyben elsősorban a Földmüvelésügyi Minisztérium alá tartozó tudományos intézetek munkatársai publikáltak.

\section{Magyar Királyi Vetőmagvizsgáló Állomások}

Ahhoz, hogy a gazdák versenyképesen termeljenek, szükség volt jó minőségű vetőmagra, amit a magkereskedők és a gazdálkodók magas áron szereztek be. A jelentős anyagi haszon miatt érdemes volt a vetőmagot hamisítani. A minisztérium vetőmagvizsgáló állomásokat hozott létre azért, hogy a forgalomba kerülő magtételeket megfelelően képzett szakemberek vizsgálják be, és kiszürjék a hamisításokat. A vetőmagvizsgáló állomások munkatársai figyelték a károsító gyomfajok megjelenését is, és kidolgozták ellenük a védekezést. Ezekben az intézményekben számos botanikus helyezkedett el, a budapesti állomás pedig, amelyet Degen Árpád vezetett, a florisztikai kutatások egyik legfontosabb hazai központja volt a huszadik század első harmadában (DAPSY 1878, DEGEN 1907).

$A z$ intézmények fejlödése - Magyarországon az első magvizsgálatokat Deininger Imre (1844-1918) végezte, amikor még a debreceni gazdasági tanintézetben tanított. Miután 1874-ben Magyaróvárra került, ő kezdeményezte az első vetőmagvizsgáló állomás létrehozását, amely 1878-ban kezdte meg működését, és 1884-ig Deininger vezette (SzINNYEI 1893). A minisztérium 1881-ben Budapesten, majd 1884-ben a gazdasági tanintézetek mellett Keszthelyen, Kolozsmonostoron, Kassán és Debrecenben hasonló intézményeket állított fel (DEGEN 1907). 
A budapesti Vetőmagvizsgáló Állomás a Magyar Királyi Állatorvosi Tanintézet növénytani laboratóriumában müködött, majd 1891-ben teljesen önállósult, 1901-től pedig a második kerületi Kis Rókus utca 15. szám alatt saját helyet kapott. A magyaróvári állomást 1906-ban, a keszthelyi állomást pedig 1909-ban szüntették meg, feladatukat a budapesti állomás vette át. A növekvő feladatok miatt nőtt a munkatársak száma is, a korszak végén a budapesti állomáson 8 adjunktus és 4 asszisztens dolgozott a vezető mellett, ezzel a budapesti vetőmagvizsgáló lett az az intézmény, amely a legtöbb botanikust foglalkoztatta az országban. A debreceni Vetőmagvizsgáló Állomás 1908-ban szűnt meg, melynek feladatait a kassai Vetőmagvizsgáló Állomás vette át, így összesen három Vetőmagvizsgáló Állomás működött a dualizmus végén: Budapesten, Kolozsváron és Kassán (DEGEN 1907, KÁROLY 1912).

A budapesti Vetőmagvizsgáló Állomás vezetői - Czakó Kálmán (1843-1895), az állatorvosi iskola tanára, az oktatás mellett a budapesti Vetőmagvizsgáló Állomást is vezette. Halálakor az állomás herbáriumában 3000 növényfaj magja és 12000 herbáriumi példány volt, melynek egy jelentős részét maga Czakó Kálmán gyüjtötte. Czakónak florisztikai cikkei is jelentek meg a Természettudományi Közlönyben és a Magyarországi Kárpátegyesület Évkönyvében (ANONYMus 1895, DEGEN 1907).

Czakó halála után a 20. század egyik legjelentősebb magyar botanikusa, Degen Árpád (1866-1934; 5. ábra) került az intézmény élére, mely vezetése alatt gyorsan fejlődött. A budapesti Vetőmagvizsgáló Állomás a hazai mezőgazdasági kutatásoknak és a flórakutatásnak egyaránt fontos intézménye lett. Degen közel 250000 darabos magánherbáriummal rendel kezett, és az európai flóra alapos ismerője volt. Számos gyüjtőúton vett részt, melyek egy részét magánvagyonából finanszírozta. Több alkalommal gyüjtött a Balkánon és a Bánátban, és ezekre az útjaira gyakran kollégái is elkísérték. Degen 1902-ben indította el a Magyar Botanikai Lapokat, melyben a hazai botanikusokon kívül külföldi szaktársak is publikáltak, Degen Árpád is számos új taxont írt le a folyóiratban. A budapesti Vetőmagvizsgáló Állomás két jelentős exsiccata sorozatot is kiadott Degen vezetésével a dualizmus időszakában, a Magyar füvek gyüjteményét és a Magyar sásfélék, szittyófélék, gyékényfélék és békabuzogányfélék gyüjteményét. Élete egyik fö müve a Flora Velebitica volt, mely négy kötetben dolgozta fel a hegység flóráját. Bár a munka általános része már 1916-ban elkészült, a részletes fejezeteket pedig 1923-ban befejezte Degen, nyomtatásban csak halála után, 1936-1938-ban jelent meg a flóramonográfia (LENGYEL 1936, DEGEN 1936, 1937, 1938a, 1938b).

Adjunktusok, segédek, preparátorok a budapesti Vetömagvizsgáló Állomáson A Vetőmagvizsgáló Állomás szakemberei gazdasági iskolában vagy egyetemen végeztek (DEGEN 1922). Számos olyan munkatársa volt az intézménynek, aki a flórakutatásba is bekapcsolódott, és segítette Degen Árpád munkáját. Alföldi 


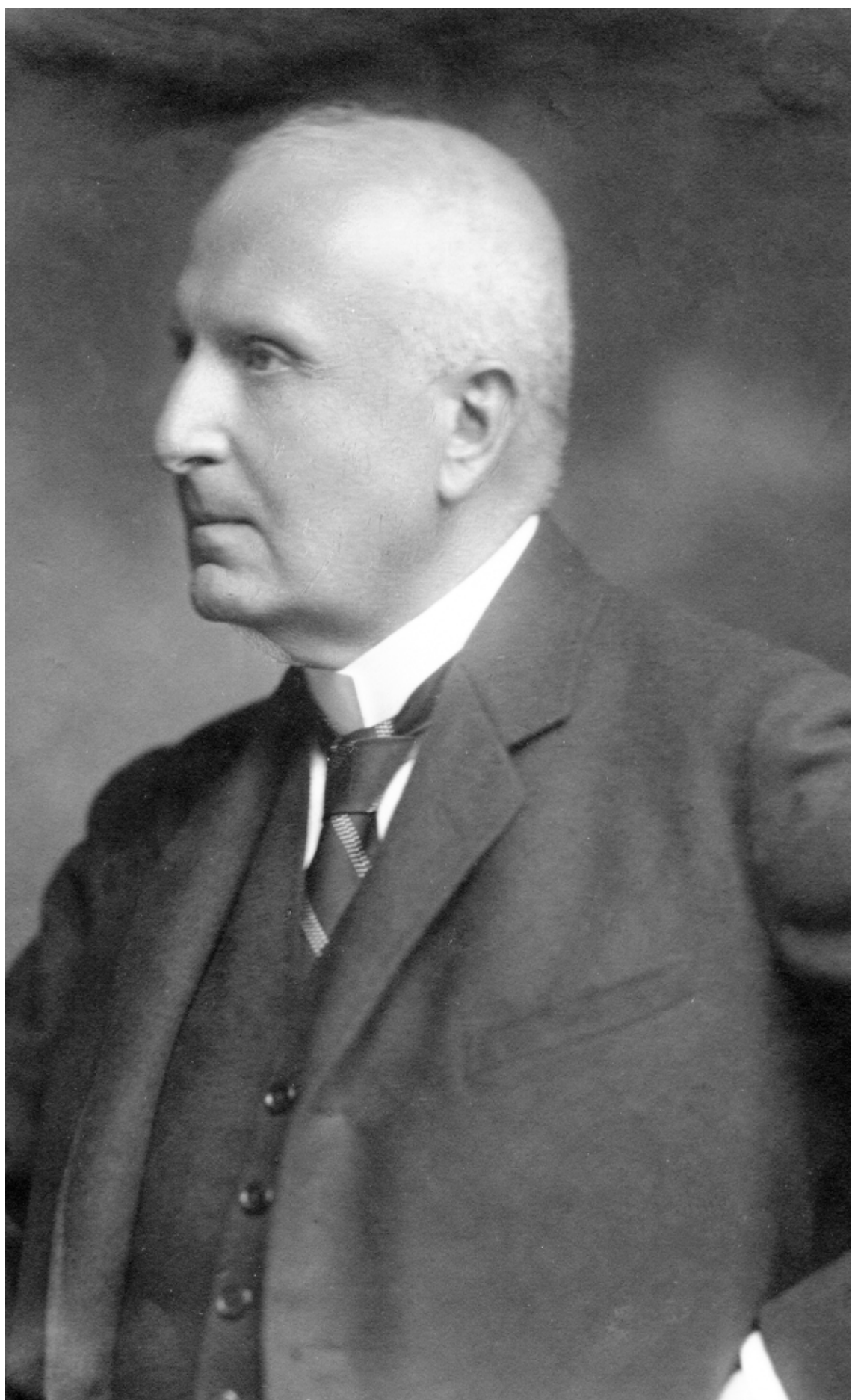

5. ábra. Degen Árpád, a budapesti Vetőmagvizsgáló Állomás igazgatója. Fig. 5. Árpád Degen, director of the Budapest Seed Testing Station. 
Flatt Károly, Thaisz Lajos és Lengyel Géza a Magyar Botanikai Lapok szerkesztésében vettek részt. A Velebit hegység kutatásába elsősorban Lengyel Géza és Kocsis István kapcsolódtak be. A Magyar füvek gyüjteményét Degen Árpád Thaisz Lajossal és Alföldi Flatt Károllyal közösen adta ki, a Magyar sásfélék, szittyófélék, gyékényfélék és békabuzogányfélék gyüjteményét pedig a budapesti intézet több korábbi munkatársa is segített összeállítani. A vetőmagvizsgáló intézetek dolgozói közül Degen Árpádon kívül Alföldi Flatt Károly, Baán Lajos, Butujás Gyula, Lengyel Géza, Thaisz Lajos, Torday György és Zsák Zoltán is gyüjtött növényeket az exsiccatákhoz. Az intézet herbáriumának gyarapításába pedig Földváry Dezső és Szartorisz Béla is bekapcsolódott (TAKÁcs et al. 2015).

Az intézmény dolgozóin kívül gyüjtött példányokat az exsiccaták számára az olasz nemzetiségű Smoquina Antal (Antonio Smoquina, 1882-1957), a fiumei reáliskola tanára is, aki a Velebit hegység kutatásában is részt vett. Smoquina Antal 1901 és 1906 között a Budapesti Egyetemre járt, feltehetőleg itt ismerte meg Degen Árpádot, aki abban az időszakban az egyetem magántanára volt (CoSULICH 1991, PifKó 2018a).

A vezető munkáját kezdetben csak egyetemi hallgatók segítették. Schilberszky Károly (1863-1935) egyetemi tanulmányai utolsó időszakában (1887-1889) volt Czakó asszisztense. Miután elvégezte a Budapesti Egyetemet, tanársegédként helyezkedett el, majd a Kertészeti Tanintézet tanára lett (Husz 1938). Thaisz Lajos (1867-1937) szintén egyetemistaként lett az intézmény munkatársa 1889-ben, és egészen 1907-ig dolgozott itt, majd 1910-ig a kassai állomást vezette. Miután Kassáról távozott, a Földművelésügyi Minisztériumba került, ahol a rét- és legelőgazdálkodási ügyek vezetője volt. Elsők között szorgalmazta a rét- és legelőgazdálkodás tudományos kutatását, neve összekapcsolódott a zöldmezőmozgalommal is, amely a takarmánynövények termesztését próbálta megoldani a Trianon után hegyi legelők nélkül maradt országban. Aktív szerepet játszott a hazai flórakutatásban, főleg az Északkeleti-Kárpátok és az Alföld növényzetét tanulmányozta, 9000 darabos herbáriumát már 1932-ben a Nemzeti Múzeum Növénytani Osztályának ajándékozta (MoESz 1941, SURÁNYI 1992).

Szabó Imre (1876-1929; hallgató: 1896-1900) budapesti egyetemi tanulmányai alatt, 1897-1898-ban dolgozott az intézetben. Ezután Szegeden tanított, ahol Lányi Bélával is kapcsolatban volt, növénygyüjteményét részben Degen Árpádnak, részben a szegedi állami föreáliskolának ajándékozta, melynek természettudományi gyüjteményét is ő felügyelte. Példányai megtalálhatóak a szegedi Móra Ferenc Múzeumban is. Szeged után, akárcsak Lányi Béla, Trencsénbe ment tanítani, az első világháború után pedig visszatért szülővárosába, Szombathelyre, ahol az állami leánygimnáziumban tanított, emellett továbbra is foglalkozott botanikával (ANONYMus 1904, Degen 1922, Csongor 1960, Horváth 1966, BALOGH 2005). 
Szintén a Budapesti Egyetemről került az intézménybe Leffler András (1879-1908), korábbi egyetemi tanársegéd, aki 1903-tól dolgozott az állomáson, ő segített Degennek összeállítani Borbás Vince bibliográfiáját (DEGEN 1905). Leffler András elsősorban növényanatómiával foglalkozott, de korai halála megakadályozta, hogy pályája kiteljesedjen. Szartorisz Béla 1902-től volt az állomás munkatársa, $s$ bár ő is a Budapesti Egyetemen végzett, elsősorban agrobotanikai témában jelentek meg publikációi.

Lengyel Géza már hallgató korában, 1904-ben itt dolgozott, és a hivatali munka mellett a flórakutatásba is bekapcsolódott. Részt vett a velebiti gyüjtőutakon, több tudományra új fajt közösen írtak le Degen Árpáddal, Degen halála után pedig ő készítette elő kiadásra a négykötetes Flora Velebitica-t. Az ország szinte egész területén botanizált, de különösen sokat gyüjtött az AlacsonyTátrában. Számos kritikus nemzetséggel is foglalkozott. Nagy szerepe volt a hazai méhészeti botanika megteremtésében is. A két világháború között a botanikai élet egyik fontos személyisége volt, számos feladatot vállalt a Botanikai Szakosztályban, szerkesztette a Botanikai Közleményeket és a Magyar Botanikai Lapokat is. Jelentős méretű herbáriumát a Magyar Természettudományi Múzeum őrzi (KÁRPÁTI 1967).

Földváry Dezső (1884?-1920) 1906-ban végzős hallgatóként került az állomásra, és haláláig annak munkatársa maradt. Még hallgatóként kísérte el Lendl Adolfot (1862-1943) kis-ázsiai útjára. Földvárynak az 1910-es években több botanikai cikke is megjelent, illetve a Flora Velebitica szerkesztésébe is bekapcsolódott (Lendl 1906, FöldVÁRY 1911, Degen 1938). Bocskay Ottó (1880-?), aki tanulmányait a Kolozsvári Egyetemen kezdte, majd a Budapesti Egyetemen fejezte be, 1908-tól dolgozott az állomáson. Bocskay az 1910-es évek első felében gyüjtött növényeket Budapest környékén (GulYás 1941, TAKÁcs et al. 2015). Viski Jenő (1887?-1918) 1911-től szintén a vetőmagvizsgálóban kapott állást. Viskinek több cikke is megjelent a Kisérletügyi Közleményekben, melyek elsősorban az intézetben végzett munkájához kapcsolódtak.

Szatala Ödön (1889-1958) kiváló lichenológus 1913 és 1920 között dolgozott az intézményben, ő állította össze a Flora Velebitica zuzmókról szóló fejezetét. A Tanácsköztársaság bukása után „politikai magatartása miatt” el kellett hagynia az intézetet, ahova csak 1927-ben térhetett vissza. Magyarországon és a Balkánon is kutatott, több mint 150 új zuzmótaxont írt le (ALLOdiatoris 1959, Boros és BoHus 1959, Verseghy 1963).

A Nemzeti Múzeum Növénytani Osztályával szemben, a Vetőmagvizsgáló Állomásra nemcsak a Budapesti Egyetemről kerültek hallgatók, hanem a Kolozsvári Egyetemen végzett botanikusok is kaptak itt munkát (PI FKó 2018a). Butujás Gyula (1881-?) 1906-ban a budapesti, 1907-ben a kolozsvári Vetőmagvizsgáló Állomáson kapott állást, a háború idején pedig a kassai vetőmagvizsgáló mun- 
katársa volt. Az orosz fogságból hazatérve újra a budapesti Vetőmagvizsgáló Állomásnál helyezkedett el (GYöRFFY 1943). Zsák Zoltán (1880-1966), aki a Kolozsvári Egyetemen volt tanársegéd, 1908-ban került az intézethez. Zsák rövidebb megszakításokkal nyugdíjazásáig, 1945-ig dolgozott itt. Intézeti munkája mellett florisztikai és rendszertani cikkeket is publikált, jelentős gyüjteményt hagyott hátra, amit ma a Magyar Természettudományi Múzeum Növénytára őriz (KÁRPÁTi 1970). Papp Lénárd, aki doktori disszertációját a Kolozsvári Egyetemen a Pulsatilla pratensis var. zichyi Schur-ról írta 1913-ban, ugyanebben az évben került a vetőmagvizsgálóba (Soó 1932).

Az intézménynek egyre több magtételt kellett átvizsgálni, ezért számos gazdasági iskolában végzett szakembert is alkalmaztak. Bár ezek a munkatársak elsősorban agrártémában publikáltak, ők is bekapcsolódtak a flórakutatásba, elkísérték Degen Árpádot útjaira, vagy az intézmény által kiadott exsiccatákhoz gyűjjtöttek növényeket (DEGEN 1922, TAKÁcs et al. 2015).

Magyaróváron végzett Schmidt Oszkár (1863-?), aki 1896-tól volt a budapesti állomás segédje, később a kassai, majd a kolozsvári állomásokon dolgozott (SzinnYei 1908). Hegyi Dezső (1873-1926) okleveles mezőgazdász 1897-1898ban volt az állomás munkatársa, később a Növényélettani Kísérleti Állomást is vezette (KENYERES 1967). Torday (vagy Tordai) György 1899-től volt az intézet segédje, elsősorban magtételek vizsgálatával foglalkozott, ezzel kapcsolatban jelent meg néhány írása, illetve ő adta ki $A$ legfontosabb gazdasági magvak gyüjteményét tíz részben, emellett Budapest környékéről is számos florisztikai adata volt (DEGEN 1922).

Alföldi Flatt Károly (1853-1906) a magyaróvári agráriskolában végzett, és élete jelentős részében különböző gazdaságokat irányított. Flatt szerepet vállalt a hazai flórakutatásban is, ennek is köszönhette, hogy 1900-tól a budapesti Vetőmagvizsgáló Állomáson kapott állást. Elsősorban botanikatörténettel foglalkozott, de jelentős herbáriuma is volt, 1902-től 5 éven át szerkesztette a Magyar Botanikai Lapokat (DEGEN 1906).

Gerhard Guido (1876-1939) a kassai gazdasági tanintézetben végzett, 1902-től napidíjas volt a Vetőmagvizsgáló Állomáson, jelentős maggyüjtemények kiadásában is részt vett, saját maggyüjteménye pedig a Nemzeti Múzeum Növénytani Osztályára került (LENG YEL 1939). Baán Lajost (1876-?), aki korábban a kassai állomáson dolgozott, 1903-ban nevezték ki segédnek a budapesti vetőmagvizsgálóba, majd Thaisz Lajos távozása után újra a kassai állomást vezette. Baán többször elkísérte Degen Árpádot és Thaisz Lajost a gyüjtőútjaikon, és ő maga is gyüjtött növényeket (DEGEN 1904, GulYás 1940, TAKÁcs et al. 2015). Kozma Dénes (1875-1925) Magyaróváron végzett, 1898-tól Magyaróváron, majd Keszthelyen volt tanársegéd, 1903-tól dolgozott a Vetőmagvizsgáló Állomáson. Kozma elsősorban a Cuscuta fajok okozta károkkal foglalkozott (KenYeres 
1967). Az intézmény munkatársa volt még Jakubovich Jenő, Kovách Géza, Kund Pál, Mészáros Dezső és Mücke Henrik is, akik szintén okleveles gazdaként kerültek a budapesti állomásra (DEGEN 1922).

Kocsis István (?-1916) már 1898-ban az intézetben dolgozott mint napidíjas szolga, 1900-ban pedig véglegesítették az állásában. Kocsis nemcsak preparátorként segítette a florisztikai kutatásokat, hanem növényeket is gyüjtött; elsősorban Budapest környékén, de a Velebit hegységben is botanizált. Ö gyüjtötte a Karlobag fölötti Velinac hegyen a Sibiraea croatica első példányait is, amely fajt később Degen Árpád írt le (LENGYel 1936).

A vidéki vetömagvizsgáló állomások - A vidéki vetőmagvizsgálókat a gazdasági akadémiák mellett hozták létre, így általában az iskolák tanárai vezették az intézményeket. A tanítás és a hivatali munka mellett kevés idejük maradt kutatásra (FEHÉR 1994). Magyaróváron Deininger Imre után Linhart György került az állomás élére. Keszthelyen Hensch Árpád (1874-1913), Zalka Zsigmond (1861-1931), majd Czakó Béla volt az állomás vezetője. Debrecenben Kerpely Kálmán (1864-1940), Juhász Árpád (1876-1964), Müller Ottó és Sztankovics János (1869-1938) is a gazdasági iskolában tanított, miközben az állomást irányította. Kolozsmonostoron Szaniszló Albert (1844-1913), Páter Béla (1860-1938), majd Juhász Árpád volt az állomás vezetője. A kassai Vetőmagvizsgáló Állomást Hazslinszky Frigyesnek (1818-1896), a korszak meghatározó botanikusának a fia, Hazslinszky Gyula (1847-1929) vezette, aki, akárcsak az őt követő Gerlóczy Géza (1867-1903), Budaházy Imre és Kovácsy Béla (1861-1931), a kassai gazdasági iskolában tanított; őket később a budapesti állomásról érkező Thaisz Lajos, majd Baán Lajos váltotta a vezetői pozícióban.

\section{A Magyar Királyi Növényélet- és Kórtani Állomás}

A Növényélet- és Kórtani Állomást Magyaróváron, a gazdasági iskola mellett működő Vetőmagvizsgáló Állomáson belül hozták létre. Az intézmény mezőés kertgazdasági növényekkel foglalkozott, a kutatáson kívül a felvilágosítás és a tanácsadás is a feladatai közé tartozott. Az intézményben dolgozó botanikusok elsősorban mikológiával és növényélettannal foglalkoztak, így a flórakutatásban csak kisebb szerepet játszott az állomás, de több olyan Budapesten végzett botanikus is munkát kapott itt, aki aktívan részt vett a hazai botanikai életben, így a Botanikai Szakosztály vagy a Kisakadémia üléseit is látogatta.

$A z$ intézmény fejlódése - A Magyaróvári Magyar Királyi Vetőmagvizsgáló, Növényélet- és Kórtani Állomás 1897-ben jött létre Linhart György kezdeményezésére. Az 1900-as években már egy vegyész, illetve adjunktus és 1-3 asszisztens is dolgozott az intézetben a vezető mellett. A magyaróvári Vetőmagvizsgáló Állomás feladatait 1906-ban a budapesti intézmény vette át, ettől kezdve a Növényélet- és 
Kórtani Állomás önállóan működött 1913-ig. Az intézetet az első világháború kezdete előtt, 1914 tavaszán költöztették át Budapestre az Ampelológiai Intézet egyik épületébe, ahol az első világháború alatt hadikórház működött, és így az állomás csak kisebb területen végezhette a munkáját (KERN 1922).

Vezetők - Az állomás első vezetője Linhart (Linhardt, Linnhardt) György volt (vezető: 1897-1910), aki gyakorlati szakemberként elsősorban a répa betegségeit kutatta, de a gabonafélék és a szőlő gombás betegségeivel is foglalkozott. Egyik fö müve a Fungi Hungarici exsiccata gyüjteménye volt, melynek öt kötete összesen 498 gombát és 2 baktériumot tartalmazott. Ebben a kiadványban 14 új fajt írtak le, ezek közül hatot maga Linhart György (PAÁL 1926, RA PAICs 1926). Hegyi Dezső (1873-1926; vezető: 1910-1919) már 1889-től az állomáson dolgozott, elsősorban különböző haszonnövények gombás megbetegedéseivel és az ellenük való védekezéssel foglalkozott, 1910-től 1919-ig pedig ő vezette az intézményt (KENYERES 1967).

Az intézmény munkatársai - Számos olyan egyetemet végzett kutató került az állomásra, aki már hallgató korában megkezdte tudományos pályáját a fóvárosban. A Müegyetem tanársegéde Francé Rezső (1874-1943) 1897-től dolgozott az intézetben, ahol patogén gombák kutatásával foglalkozott. Francé 1901-ben hagyta el Magyaróvárt és családjával együtt Németországba költözött (PRISZTER 1994). Doby Géza (1877-1968) a Budapesti Egyetemen végzett, 1905-től 1913-ig vegyészként dolgozott a magyaróvári állomáson, majd innen a Mezőgazdasági Vegykísérleti Állomásra ment át. Doby Géza intézeti munkája során elsősorban növényi enzimekkel foglalkozott, őt tekinthetjük hazánkban a növény-biokémiai tudomány megalapozójának, eredményeit a Botanikai Szakosztály ülésein is rendszeresen bemutatta (LENGYEL 1927, Soós 1979).

Paál Árpád (1889-1943), aki már egyetemi évei alatt is növényélettannal foglalkozott, a Budapesti Egyetem Növénytani Intézetében volt tanársegéd, innen került 1915-ben az akkor már Budapesten mủködő Növényélet- és Kórtani Állomásra. A gombás megbetegedések kutatásán kívül elsősorban növényélettani vizsgálatokat bíztak rá. Miután 1929-ben Mágócsy-Dietz Sándort (1855-1945) nyugdíjazták, ő lett a Budapesti Egyetem Növénytani Intézetének a vezetője (FrENYó 1993).

$\mathrm{Az}$ egyetemet végzett munkatársakon kívül számos agrárvégzettségű szakember is dolgozott az állomáson. Az osztrák származású Kern Herman (18761957) 1902-ben került az intézetbe, amelyet a két világháború között vezetett is. Elsősorban a haszonnövények gombás megbetegedéseivel foglalkozott, a hazai növényvédelem egyik megalapozója volt, ő dolgozta ki a növény-egészségügyi szolgálat tervezetét is (JÁNOSsY 1957). Beke László (1881-1950), aki 1910-től 1912-ig, majd 1920-tól 1928-ig dolgozott az intézményben, Magyaróváron végzett, és a gazdasági akadémián is tanított, elsősorban a burgonya betegségeivel foglalkozott (KENYERES 1967). 
A Magyar Királyi Központi Szőlészeti Kísérleti Állomás és Ampelológiai Intézet

Az 1800-as évek utolsó évtizedeiben fellépő filoxérajárvány okozta sokk miatt a minisztérium fontosnak tartotta, hogy egy olyan modern intézetet hozzanak létre, ahol a szőlő növényt, annak kártevőit, és a borkészítés módszereit kutatják. Az Ampelológiai Intézet Darányi Ignác földművelésügyi miniszter kezdeményezésére, Istvánffi Gyula tervei alapján jött létre 1898-ban. Több tehetséges botanikus, flórakutató helyezkedett el itt, de a hivatali munka mellett csak kevés idejük maradt arra, hogy a flórakutatásban is részt vegyenek. Az itt dolgozó botanikusok publikációi elsősorban az intézményben folyó kutatásokhoz kapcsolódtak (Soós 1988).

Az intézmény fejlödése - Az Országos Filoxéra Kísérleti Állomást 1880-ban hozták létre, fö feladata a filoxérával kapcsolatos kutatás és a kártevők elleni védekezés módjainak vizsgálata volt. Az állomás neve az 1890-es átszervezés után Állami Rovartani Állomás lett. Darányi Ignác Istvánffi Gyulát bízta meg 1896-ban, hogy készítse el egy olyan intézet terveit, amely összefogja a szőlő növénnyel és a borkészítéssel kapcsolatos kutatásokat. A szervezés és berendezés feladatán kívül az intézet vezetését is Istvánffira bízták. Az intézetben, amely 1898-ban jött létre, négy osztály működött: élettani osztály (növényélettan és kórtan), vegyészeti osztály (tudományos borászat), gombászati osztály (erjedés tanulmányozása), szőlészeti és borászati osztály (gyakorlati kísérletezések) (DicENTy 1922, Soós 1988).

$\mathrm{Az}$ intézet kezdetben 3 helyiségben müködött, egészen 1904-ig, amíg el nem készült a Törökvész dűlőn (ma Herman Ottó út) az új épületegyüttes, amely Európa egyik legkorszerübb tudományos intézete volt 5 épületében 322 helyiséggel. Ebben a hatalmas intézetben az állami költségvetésből csak kevés kutatót tudtak alkalmazni, ezért 1913-ban Degen Árpádot bízták meg azzal, hogy tervezze meg az Ampelológiai Intézet épületeiben müködő, összevont Országos Mezőgazdasági és Szőlészeti Intézet felállítását. Ebben a tervek szerint 9 önálló osztály kapott volna helyet, többek között a növénykórtani, növényélettani, szőlészeti, vetőmag-vizsgálati, gyógynövény-kísérleti osztályok. 1913-ban még Istvánffi Gyula volt az Ampelológiai Intézet igazgatója, így Degen megbízása mindkét botanikus számára problémát jelentett. Az első világháború alatt az épületekben hadikórház működött, így az intézmény újjászervezése csak a háború után valósult meg, de ebben már sem Degen Árpád sem Istvánffi Gyula nem játszott vezető szerepet (DiCENTY 1922, DeGEN 1932, LENG YEL 1936).

Vezetők - Az 1898-ban létrejött intézetet szinte a teljes tárgyalt időszakban, egészen 1915-ig, Istvánffi Gyula (6. ábra) vezette, aki korábbi egyetemi és múzeumi munkája során elsősorban algákkal és gombákkal foglalkozott. Az intézetben töltött évek alatt a szőlőn élősködő gombák életét kutatta, legjelentősebbek a peronoszpórával kapcsolatos eredményei voltak (DEGEN 1932, MÁGócsYDieTz 1932). 
Degen Árpádot 1915-ben bízták meg az intézmény vezetésével, azzal a céllal, hogy a mezőgazdasági kutatások számára egy nagy, központi intézetet szervezzen meg a túlméretezett Ampelológiai Intézet helyén. Degen nem szívesen vállalta el a feladatot, és miután az első világháború utáni zavaros politikai időkben „sok és igaztalan támadás” érte, lemondott az intézmény vezetéséről (LENGYEL 1936).

Munkatársak - Az intézetben vegyészeken és borászokon kívül számos tehetséges, egyetemen vagy gazdasági iskolában végzett botanikus is állást kapott.

Istvánff, aki maga is a Kolozsvári Egyetemen tanult, kezdetben több, Erdélyből származó szakembert is meghívott az intézetébe dolgozni. Tompa Arthur (1872-1944), aki Kolozsváron született és a kolozsmonostori gazdasági akadémián, majd a Budapesti Egyetemen végzett, 1900-tól 1905-ig dolgozott az Ampelológiai Intézetben növénytani asszisztensként. A két világháború között gazdasági újságírással foglalkozott Erdélyben, számos cikke jelent meg szőlészeti témában (SZINNYEI 1914). Bálint Sándor (1860-1922), aki 1901-től egészen 1912-ig dolgozott az Ampelológiai Intézetben a kolozsvári egyetemen végzett, 1887-től az állat- és összehasonlító bonctani tanszék tanársegédje lett, majd 1890-től az Erdélyi Múzeum állattani gyüjteményében dolgozott, ezek után került Budapestre (KeNYEREs 1967).

Bernátsky Jenő, aki a Nemzeti Múzeumban Istvánffi munkatársa volt, 1905ben került az intézetbe. Kezdetben kalapos gombákkal foglalkozott, később a szőlészet, a gyümölcstermesztés és a növénykórtan területén ért el eredményeket (JÁvor KA 1957).

Anisits (Anisich) Dániel (1856-1911), miután hazatért Paraguayból, egy rövid ideig (1907-1908) az intézetben dolgozott, melynek igazgatójával, Istvánffi Gyulával már paraguayi tartózkodása idején is levelezett. A zalaegerszegi származású Anisits 1877-ben végzett gyógyszerészként a pesti egyetemen, majd 1883ban elhagyta az országot és Paraguayba költözött, ahol 1889-ben az állam első felsőoktatási intézményében a bakteriológia oktatásával bízták meg. Egyetemi munkája mellett növényeket is gyüjtött. Herbáriumát neves magyar és külföldi kutatóknak küldte el feldolgozásra, a páfrány anyagát például a Nemzeti Múzeum munkatársa, Kümmerle Jenő Béla határozta. Paraguayi gyüjtéseiből számos új taxont írtak le (Nemes 1999), többek közt két új zuzmófajt is: Ramalina anisitsiana, $R$. paraguayensis (GYELNIK 1931).

Wéber Dezső (1883-1952) szintén gyógyszerészként végzett a Budapesti Egyetemen, 1908 és 1910 között dolgozott az intézetben, ahol filoxérával kapcsolatos kutatásokat végzett (ZвоRAY 1985).

Sántha László (1886-1954) tanulmányait Budapesti Egyetemen végezte, ahol 1908 és 1910 között díjazott gyakornok volt a Növénytani Intézetben, majd 1909-től az Ampelológiai Intézetben dolgozott. Sántha növényvédelemmel és a 


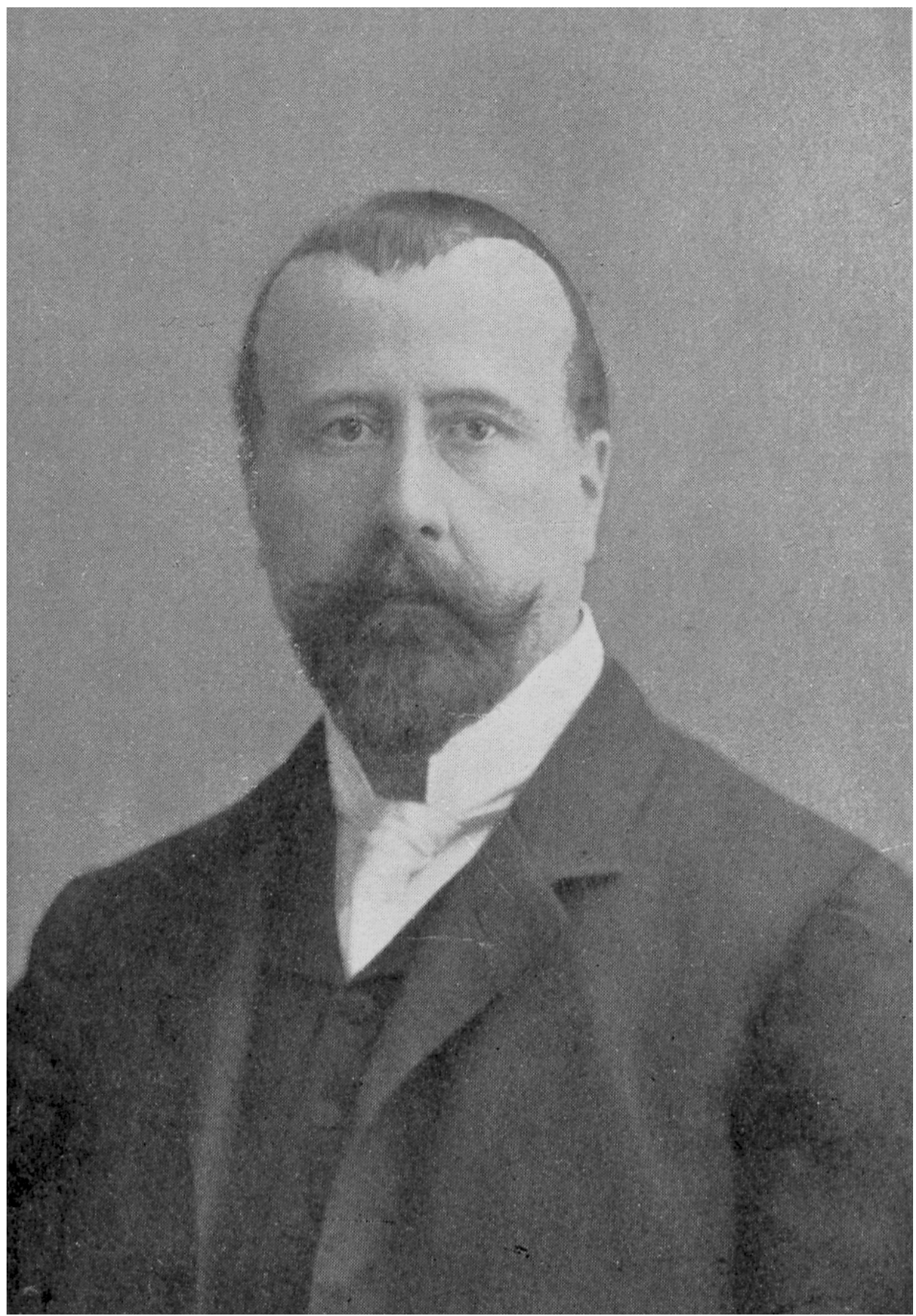

6. ábra. Istvánffi Gyula, a Központi Szőlészeti Kísérleti Állomás és Ampelológiai Intézet első igazgatója.

Fig. 6. Gyula Istvánffi, the first director of the Central Viticultural Experimental Station and Ampelological Institute. 
szőlő kórtanával, elsősorban a peronoszpóra és a lisztharmat vizsgálatával foglalkozott, de a hivatali munkája mellett a zuzmókat is kutatta. Pályája első évtizedeiben számos cikke jelent meg zuzmókról, elsősorban a Botanikai Közleményekben (KenYeRES 1969).

Andrasovszky József (1889-1943) már 1911-ben, amikor még a Budapesti Egyetem hallgatója volt, részt vett egy kis-ázsiai expedíción, melynek eredményeit publikálta is (ANDRAsovszKY 1914). Az egyetem után 1912-től helyezkedett el az intézetben. Munkássága a szőlőfajták tudományos rendszerezése és feldolgozása területén alapvető volt, ő írta a Magyar Flórában a Vitis nemzetség határozókulcsát (JÁvORKA 1925). A magyar botanikusok közül elsőként járt és gyüjtött növényeket Albániában az első világháború idején, amikor már az intézet munkatársa volt. Ezt az útját a Magyar Tudományos Akadémia támogatta (KenYeREs 1967, BARINA et al. 2017).

A kolozsvári gyógynövénytelep és a Magyar Királyi Gyógynövénykísérleti Állomás

A magyar állam már a huszadik század elején támogatott olyan intézményeket, melyek feladata a gyógynövények termesztése és a hatóanyagok vizsgálata volt. A gyógynövények kutatásába már ekkor kiváló botanikusok kapcsolódtak be, de a Gyógynövénykísérleti Állomás jelentősebb kutatóintézetté csak az első világháború után fejlődött.

A Földművelésügyi Minisztérium 1904-ben gyógynövény-kísérleti telepet létesített a kolozsvári Gazdasági Tanintézet mellett, melynek vezetésével az iskola tanárát, Páter Bélát bízták meg, aki egészen 1931-ig vezette az intézményt. A gyógynövénytelep eleinte szerény körülmények között működött, de 1909-től már kémiai laboratóriuma is volt, melynek vezetésével Irk Károlyt (1882-1924) bízták meg. 1912-től a gyógynövények betegségeivel is rendszeresen foglalkoztak az intézményben, emellett a nyári hónapokban gyógynövény-tanfolyamokat szerveztek (V. Góz 1990).

A minisztériumnak az volt a terve, hogy a Kolozsváron elszigetelten működő gyógynövény-kísérleti állomás mellett egy új, gyógynövényekkel foglalkozó tudományos intézetet hoznak létre Budapesten. Degen Árpád tervei szerint az újonnan létrehozott Mezőgazdasági Növénytani Intézeten belül jött volna létre egy gyógynövényosztály, de a minisztérium végül önálló Gyógynövénykísérleti Állomás létesítése mellett döntött, melynek első lépéseként 1915-ben megbízták az Ampelológiai Intézetet, hogy teremtse meg az önálló állomás létesítésének feltételeit. Az állomás létrehozásával és igazgatásával Irk Károlyt bízták meg, akit Kolozsvárról helyeztek át Budapestre 1915-ben. Az ő munkáját segítette Augusztin Béla (1877-1954), aki 1913-tól dolgozott az Ampelológiai Intézetben. 
Az 1918-tól önállóan működő intézmény vezetését Augusztin Béla vette át, aki gyógyszerészként végzett a Budapesti Egyetemen, ahol később ő oktatta a növénytant a gyógyszerész hallgatóknak. Az állomáson a háború alatt megkezdték azoknak a növényeknek a termesztését, melyek a hazai drogpiacon a háború miatt hiányoztak, illetve megszervezték és irányították a „szedercserje” levelek gyüjtését, amiből a hadsereg részére teapótló anyagot állítottak elő (AUGUSZTIN 1922, TÉTÉNYi 1995, SZABó 2015, SZMOdits 2015).

\section{A Magyar Királyi Erdészeti Kísérleti Állomások}

A gazdaság fejlődése egyre nagyobb terhet rótt a hazai erdőállományokra. A növekvő vágásterületeken szükség volt a szakszerű felújításokra, az ország faállományának szakszerü kezelése pedig nemzeti érdek volt. A minisztérium az Országos Erdészeti Egyesület kezdeményezésére Erdészeti Kísérleti Állomásokat hozott létre. A központi állomás a selmecbányai Bányászati és Erdészeti Akadémia, később Főiskola mellett működött. A kísérleti állomásokon olyan, Selmecbányán végzett szakemberek dolgoztak, akik megfelelő botanikai ismeretekkel is rendelkeztek, $s$ bár elsősorban az erdőműveléssel kapcsolatban végeztek kutatásokat, néhányan közülük a hazai flóra kutatásába is bekapcsolódtak (FüHRER és SOLYMOs 2008).

$A z$ intézmény fejlődése - Az Országos Erdészeti Egyesület már 1874-ben állást foglalt az erdészeti kísérletügy megszervezése mellett. Vadas Jenő, a selmecbányai akadémia tanára, 1893-ban javaslatot tett a hazai erdészeti kísérletügy megszervezésére. Darányi Ignác földművelésügyi miniszter 1897. december 31-én írta alá azt a rendeletet, amely biztosította az erdészeti kísérleti állomások felállítását. A selmecbányai Központi Erdészeti Kísérleti Állomáson kívül az erdőőri szakiskolák mellett négy külső kísérleti állomást hoztak létre 1898ban, Temesvár-Vadászerdőn (Románia, Timișoara), Liptóújváron (Szlovákia, Liptovský Hrádok), Görgényszentimrén (Románia, Gurghiu) és Királyhalmon (ma Ásotthalom). A központi állomás vezetője, Vadas Jenő, új folyóiratot is indított 1899-ben Erdészeti Kisérletek néven, melyben az állomások munkatársain kívül a selmecbányai Bányászati és Erdészeti Akadémia, később Főiskola tanárai és más erdészeti szakemberek is publikálták kutatási eredményeiket (FÜHRER és Solymos 2008).

$A z$ intézmény munkatársai - A Központi Erdészeti Kísérleti Állomást az egész vizsgált időszakban Vadas (Vlkolinszky) Jenő (1857-1922) vezette. Az ő szervező munkájának köszönhető elsősorban, hogy a központi állomás mellett a Kárpát-medence más régióiban is kísérleti állomásokat állítottak fel. Munkái közül kiemelkedik az 1911-ben kiadott akácmonográfiája, ami német nyelven is megjelent. Tudományos munkája mellett a Bányászati és Erdészeti Akadémián, 
majd annak átalakulása után a főiskolán is oktatott. Vadas irányításával hazánkban készültek megrendezni 1914-ben az Erdészeti Kutatóintézetek Nemzetközi Szövetségének VII. kongresszusát, mely azonban az első világháború miatt elmaradt. A trianoni békeszerződés az erdészeti kísérleti állomásokat a királyhalmi állomáson kívül elcsatolta Magyarországtól. Az események megviselték Vadas Jenőt, ami korai halálában is szerepet játszott (Rотн 1922).

Tuzson János (1870-1943) 1898-tól volt a Központi Erdészeti Kísérleti Állomás adjunktusa, ebben az időszakban elsősorban szövet- és sejttannal foglalkozott. Bár 1904-től előbb a Műegyetemen, majd a Budapesti Egyetemen tanított, továbbra is foglalkozott erdészeti kérdésekkel (ANONYMUs 1940, PifKó 2018a).

Tuzson helyét Roth Gyula (1873-1961) vette át, aki 1900-ban került a görgényszentimrei kísérleti állomásra, majd 1904-től 1940-ig a központi állomás munkatársa volt, és az intézményt a két világháború között irányította is. Foglalkozott a erdészetek által használt vetőmagvak származásával, a külföldi fafajok meghonosításával, az erdőműveléssel kapcsolatos kísérletei pedig külföldön is ismertek voltak. 1907-től az erdészeti oktatásban is részt vett a föiskolán (MAGYAR 1961).

A vidéki állomások munkatársai, akik az erdőőri iskolák mellett felállított intézetekben dolgoztak, az oktatás mellett bekapcsolódtak az erdészeti kutatásokba is. Benkő Rezsőnek (Liptóújvár), Szakmáry Ferencnek (1863-?, Görgényszentimre) Török Sándornak (1864-1922, Temesvár) az Erdészeti Kisérletekben és Erdészeti Lapokban jelentek meg cikkei. Teodorovits Ferenc (1861-1929), aki a királyhalmi intézetet vezette, az oktatás és az erdészeti kutatómunka mellett herbáriumot is készített (CsONGOR 1960, KERÉNYI-NAGY 2018).

\section{Megvitatás}

A dualizmus előtt nem léteztek olyan állami fenntartású intézmények a magyar állam területén, amelyek a hazai botanikai kutatásokat megszervezték volna, illetve hátteret biztosítottak volna kutatói közösségeknek. A Széchényi Ferenc (1754-1820) kezdeményezésére létrejött Nemzeti Múzeum is elsősorban társadalmi adakozásból tartotta fenn magát (FEJős 1965), a Magyar Tudományos Akadémia pedig sem a dualizmus előtt, sem a dualizmus éveiben nem rendelkezett tudományos intézetekkel. A dualizmus előtti időszakban elsősorban olyan értelmiségiek kutatták a flórát, akik a munkájuk miatt sokat utaztak a lakóhelyük környékén vagy akár az egész országban. Legtöbben közülük vidéki orvosok és gyógyszerészek voltak, akik már az egyetemen megismerkedtek a botanikával, de a papok, tanárok és a tanítók között is voltak olyanok, akik flórakutatással foglalkoztak. Intézményi hátteret csak a Nemzeti Múzeum vagy a pesti Királyi Magyar Tudományegyetem biztosított egy-két botanikus számára. 
Az 1880-as évektől tudományos intézeteket, kísérleti állomásokat hoztak létre az agráriskolák, majd később az erdészeti iskolák mellett, melyek kezdetben elsősorban a gazdaság számára fontos vizsgálatokat végeztek. Ezek az intézetek egy-két olyan botanikust alkalmaztak, akik az állomáson végzett munkájuk mellett gazdasági iskolában tanítottak, ezért csak kevés idejük maradt a kutatásra. A korszak második felében átalakult az agrárkutatás intézményrendszere, és két nagyobb központot hoztak létre Budapesten, ahol számos botanikus kapott munkát: az Ampelológiai Intézetet és a központi Vetőmagvizsgáló Állomást. Ezeknek az intézményeknek a fő feladata a mezőgazdasággal kapcsolatos kutatás volt. A dualizmus időszakában alakult meg a Nemzeti Múzeum Növénytani Osztálya is, ahol a korszak végén hat egyetemet végzett szakember dolgozott. Elsősorban ezekben a tudományos és kulturális intézményekben helyezkedtek el az egyetemeken vagy gazdasági iskolákban végzett botanikusok, akik közül többen flórakutatással is foglalkoztak. A tudományos intézetek számos munkatársa az egyetemen is tanított mint magántanár, ami jelentősen hozzájárult a felsőoktatás színvonalának az emeléséhez (7. ábra).

A tudományos és kulturális intézetek folyóiratokat adtak ki. Az országos és vidéki egyesületek által fenntartott folyóiratok mellett ezek az intézményi háttérrel létrejött lapok jelentették a legfontosabb publikációs lehetőséget a hazai botanikusoknak. A Nemzeti Múzeum természettudományos osztályainak lapja, a Természetrajzi Füzetek, már 1877-től publikációs lehetőséget biztosított a hazai flórakutatók számára. Kimagasló jelentősége volt a Magyar Botanikai Lapoknak is, melyet Degen Árpád hozott létre és adott ki közösen szerkesztve a budapesti Vetőmagvizsgáló Állomás néhány munkatársával. Ez a lap nemcsak a hazai flórakutatás számára biztosított fórumot, számos külföldi kolléga publikálta itt a balkáni flórakutatással kapcsolatos eredményeit.

Már a dualizmus első évtizedeiben számos új városi, megyei lokálpatrióta egyesület jött létre, melyek közül több olyan múzeumot alapított, amelynek természettudományos gyüjteménye is volt. A vidéki múzeumok helyzetét egy 1897-es rendelet rendezte, ami után erősödött az állami felügyelet, és nőtt a magyar állam anyagi támogatása (Sipos 2013). Sok esetben ezek a múzeumok biztosítottak helyet a korszak első felében létrehozott olyan magánherbáriumoknak, melyeket orvosok vagy papok gyüjtöttek. A korszak második felében már jelentősebb a gimnáziumi tanárok szerepe a vidéki gyüjtemények gyarapításában, ezek a tanárok gyakran múzeumőri feladatokat is elláttak a természettudományos gyüjteményekben.

A hazai flórakutatás két legfontosabb központja, a Nemzeti Múzeum Növénytani Osztálya és a budapesti Vetőmagvizsgáló Állomás, jelentősen fejlődött az 1900-as években. A fejlődés egyik fontos eleme volt, hogy jelentősen növekedett az intézményekben dolgozó szakalkalmazottak száma. Több olyan 
nagyszabású munka is ebben a két intézetben vette kezdetét az 1900-as években, melynek eredményei már csak a két világháború között jelentek meg.

Az egyik legnagyobb jelentőségü munka Jávorka Sándor (1925) határozója, a Magyar Flóra volt, mely a Kárpát-medence teljes edényes flórájának első, és mai napig utolsó kritikai feldolgozása volt. Jávorka, miközben a hazai flórakutatás egyik központi intézményében dolgozott, sikeresen vonta be a hazai szakmát a határozó elkészítésébe. Munkatársán, Kümmerle Jenő Bélán kívül segítette Jávorka munkáját Degen Árpád, a budapesti Vetőmagvizsgáló Állomás igazgatója, aki a Rosa nemzetséget írta meg. Andrasovszky József, az Ampelológiai Intézet mun-

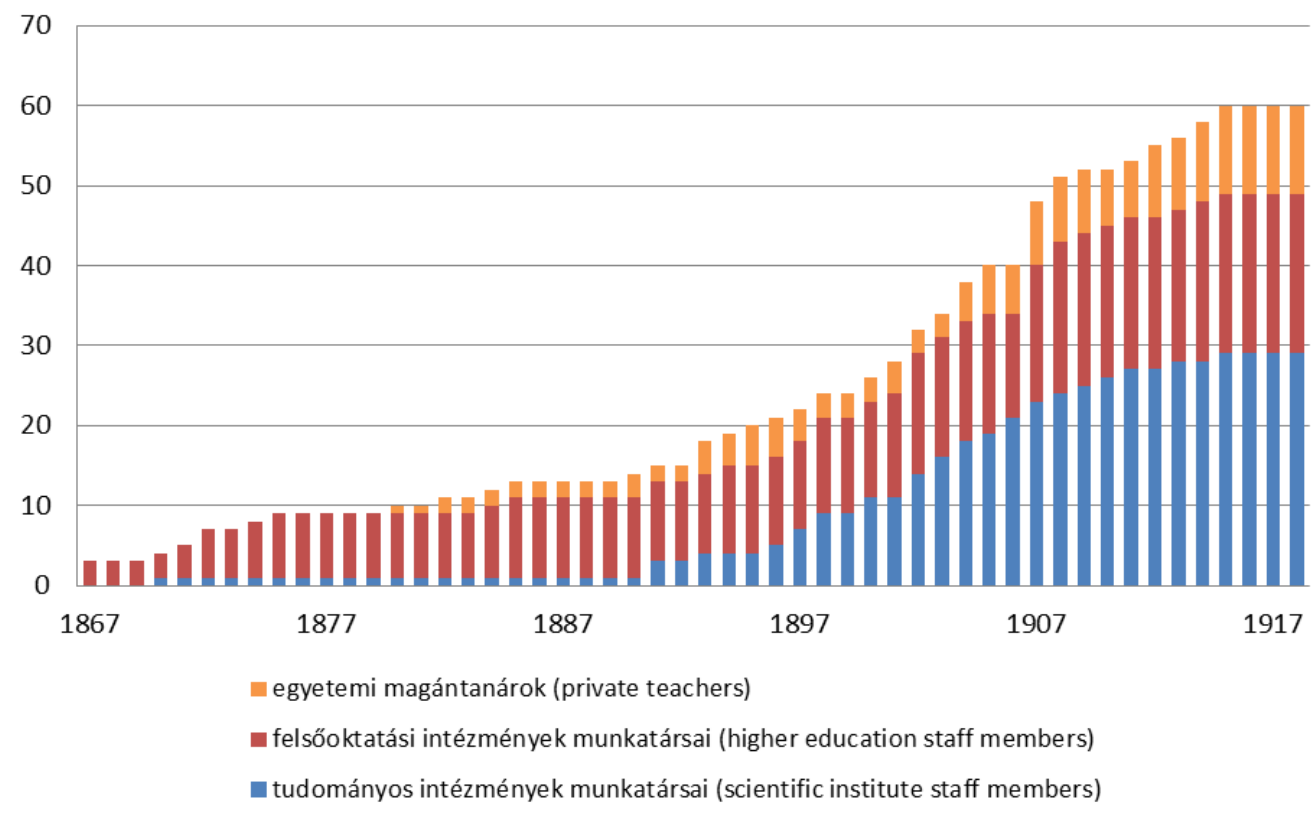

7. ábra. Az állami intézményekben dolgozó botanikusok száma a dualizmus időszakában (18671918). A tudományos intézmények munkatársai közé a Magyar Nemzeti Múzeum Növénytani Osztályának muzeológusait, a felsőoktatási intézményektől függetlenül működő agrárintézmények és a Központi Erdészeti Kísérleti Állomás botanikusait soroltuk. A felsőoktatási intézmények munkatársai közé az egyetemek növénytani tanszékein dolgozó tanárokat, adjunktusokat és tanársegédeket, az agrár akadémiák növénytanszékeinek a vezetőit, az Állatorvosi Akadémia (később Főiskola) és az Kertészeti Tanintézet növénytanszékének vezetőit, valamint a Bányászati és Erdészeti Akadémia (később Főiskola) Növénytani Tanszékének vezetőit soroltuk. Az egyetemi magántanárok csak óraadó tanárok voltak, többségük más intézményben vagy gimnáziumban dolgozott.

Fig. 7. Number of botanists in state-operated scientific institutions in Hungary during the dualistic era (1867-1918). Employees of the scientific institutions include museologists of the Botanical Department of the Hungarian National Museum, botanists of the independent agricultural, viticultural and forestry research institutes. Employees of higher education include university professors, teaching assistants and academic staff of botanical departments in schools of agriculture, forestry, horticulture and veterinary medicine. The private teachers were only part-time employees of a university, they had a job in other scientific institutions or in secondary schools. 
katársa, a Vitis nemzetség szerzője volt. Szabó Zoltán és Mágócsy-Dietz Sándor is hozzájárultak a mü elkészítéséhez, akik a Budapesti Egyetemen dolgoztak. Emellett számos „amatőr” taxonómus írt vagy lektorált fejezeteket, mint Lyka Károly (1869-1965), Gáyer Gyula (1883-1932), Trautmann Róbert (1873-1953), Gombocz Endre (1882-1945), Wagner János (1870-1955). Mivel a határozó hét évvel azután jelent meg, hogy véget ért a dualizmus időszaka, már az első világháború utáni korszak két legjelentősebb botanikusa, Soó Rezső (1903-1980) és Boros Ádám (1900-1973) is bekapcsolódott a munkába (JÁVORKA 1925).

A másik jelentős kutatás, amely a dualizmus időszakában zajlott, a Velebit hegység flórájának kutatása volt. Ezt a munkát a hazai flórakutatás másik meghatározó egyénisége, Degen Árpád szervezte, aki a budapesti Vetőmagvizsgáló Állomás vezetője volt. Az állomás munkatársai közül elsősorban Lengyel Géza, Szatala Ödön és Kocsis István segítették a munkát. A Nemzeti Múzeum botanikusa, Kümmerle Jenő Béla is sokat kutatta a hegység flóráját, az ő eredményeit Degen Árpád szintén felhasználta, amikor a hegység flóraművét készítette. A kriptogám anyag feldolgozásában a Nemzeti Múzeum Növénytani Osztályának munkatársai is részt vettek: a csillárkamoszatokat (Characeae) Filarszky Nándor, a gombákat Moesz Gusztáv határozta. Sajnos a négykötetes Flora Velebitica csak 1936-1938-ban, Degen Árpád halála után jelent meg.

Szép példa az intézmények közötti és az intézményen belüli együttműködésre az albán flóra kutatása is, amit a Magyar Tudományos Akadémia támogatott az első világháború alatt. 1916-1917-ben Andrasovszky József, az Ampelológiai Intézet munkatársa, Csiki Ernő, a Nemzeti Múzeum Állattani Osztályának entomológusa, illetve Jávorka Sándor és Kümmerle Jenő Béla gyüjtöttek növényeket észak-albán területen. Az anyagot elsősorban a Nemzeti Múzeum munkatársai dolgozták fel. A virágos növényeket Jávorka Sándor, a páfrányokat Kümmerle Jenő Béla, az algákat Filarszky Nándor és Krenner József Andor (1900-1979), a mohákat Szepesfalvy (Szurák) János, a gombákat Moesz Gusztáv, a zuzmókat pedig Szatala Ödön és Timkó György határozta. A munkához nagy segítséget jelentett Degen Árpád herbáriuma is (Teleki és Csiki 1926).

A fejlödés ellenére több, intézményi struktúrával kapcsolatos probléma is volt a korszakban, ami a flórakutatást érintette. Talán a legjelentősebb probléma az volt, hogy bár több intézményben is alkalmaztak olyan botanikusokat, akik a flórát kutatták, egyik intézménynek sem a flórakutatás volt a legfontosabb feladata. A budapesti Vetőmagvizsgáló Állomáson Degen Árpád vezetői pozíciójának köszönhető, hogy a hazai flórakutatás központjává tudott válni, annak ellenére is, hogy az intézményt a magyar mezőgazdaság támogatására hozták létre. A Nemzeti Múzeum Növénytani Osztályán pedig nagy munkát jelentett a gyüjtemények gyors gyarapodása, és az ehhez kapcsolódó adminisztráció, amely sok esetben elvette az időt a kutatómunkától. 
Szintén problémát jelentett, hogy vidéken a fejlesztések nem haladtak olyan ütemben, mint a fóvárosban. A korszak végére Budapesten már sok botanikus dolgozott oktatási, kulturális és tudományos intézményekben, ami segítette a szakemberek együttműködését. Eközben a kisebb vidéki városokban létrejött tudományos intézmények fejlődése megrekedt, a budapesti központosítás miatt több intézmény megszűnt vagy a fővárosba költözött, így vidéken továbbra is a civil kezdeményezésre létrejött egyesületek játszottak nagyobb szerepet a flórakutatásban. Kolozsváron az állami fenntartású tudományos intézményeket (vetőmagvizsgáló és gyógynövénykutató) sokáig az a Páter Béla vezette, aki a gazdasági iskolában és az egyetemen is oktatott. Ezek az intézmények legfeljebb egy-két botanikust alkalmaztak, így Erdélyben a flóra kutatásában elsősorban a Kolozsvári Egyetem Növénytani Tanszékének és az Erdélyi Múzeum Egyletnek volt vezető szerepe.

A problémák ellenére egy olyan, szinte előzmények nélküli intézményrendszer jött létre a dualizmus időszakában, amiben nemzetközi szinten is jelentős eredményeket értek el a botanikusok a Kárpát-medence és a Balkán flórakutatása terén. A budapesti intézmények szakemberei sikeresen dolgoztak együtt számos kutatási témában. A vezető intézményekben Degen Árpád és Jávorka Sándor kapcsolatot tartott a vidéki és külföldi botanikusokkal, segítették a munkájukat, és az eredményeiket is felhasználták olyan nagyszabású művekhez, mint a Magyar Flóra vagy a Flora Velebitica. Elmondható tehát, hogy a dualizmus időszakában, amikor a felsőoktatás biztosította a megfelelő szakembereket, a kulturális és tudományos intézmények azok a helyek, amelyek a hosszú távú, módszeres kutatómunkához megteremtették a hátteret. Ezekben az intézményekben jöttek létre a magyar botanika legfontosabb művei, amelyek csak szakmai összefogással valósulhattak meg.

\section{Köszönetnyilvánítás}

Szeretnék köszönetet mondani Lőkös Lászlónak a cikk készítése során nyújtott segítségért, Papp Gábornak, a Növénytár könyvtárosának az áldozatos munkájáért, és Kerényi-Nagy Viktornak, hogy a Mezőgazdasági Múzeummal kapcsolatos irodalmat a rendelkezésemre bocsátotta.

\section{Irodalomjegyzék}

ALAPI Gy. 1911: A Múzeumok és Könyvtárak Orsz. Főfelügyelősége hatáskörébe tartozó közgyűjtemények fejlődése az 1910. évben. Muzeumi és Könyvtári Értesítő 5: 168-195.

Allodiatoris I. 1959: Dr. Szatala Ödön, 1889-1958. Élővilág 4: 46-47.

ANDRAsovszky J. 1914: Adatok Galatia és Lycaonia flórájához. (Additamenta ad floram Galaticam et Lycaonicam). Fritz Ármin Könyvnyomdája, Budapest, 106 pp.

ANONYMUs 1869: Vidék. Fővárosi Lapok 6(4): 18.

ANonymus 1895: Dr. Czakó Kálmán. Köztelek 5(91): 1804. 
ANONYMUs 1904: A magyarországi múzeumok és könyvtárak czímkönyve. Magyar Minerva 3. évfolyam 1903-1904. Athenaeum Irodalmi és Nyomdai R.-társulat, Budapest, 927 pp.

ANonymus 1907: A mezőgazdasági múzeum. Budapesti Hírlap 27(136): 17-18.

ANONYMUs 1912: A Múzeumok és Könyvtárak Orsz. Főfelügyelősége hatáskörébe tartozó közgyüjtemények fejlődése az 1911. évben. Muzeumi és Könyvtári Értesítő 6: 152-187.

ANonymus 1917: A Turóczszentmártoni Tót Múzeumról és növénytani gyüjteményéről. Muzeumi és Könyvtári Értesítő 11: 256-257.

Anonymus 1940: Dr. Tuzson János. Index Horti Botanici Universitatis Budapestinensis 4: 5-11.

ANonymus 1942: Dr. Varga Sándor. Turisták Lapja 54: 157.

Augusztin B. 1922: M. kir. Gyógynövénykisérleti Állomás, Budapest, II. ker., Debrői-út 15. (Kgl. Ung. Medizinalpflanzen-Versuchsstation zu Budapest). Kisérletügyi Közlemények 25(1-4): 108-110.

Aumüller S. A., Jeanplong J. (szerk.) 1983: Carolus Clusius Fungorum in Pannoniis observatorum brevis historia et Codex Clusii. [Faksimile] Mit Beiträgen von einer internationalen Autorengemeinschaft. Akadémiai Kiadó, Akademischer Druck- und Verlagsanstalt, Budapest-Graz, $247 \mathrm{pp}$.

BAKó B. 2013: Az első magyar természettudományi múzeum herbáriuma. Természet Világa 144(7): 104-107.

BALOGH L. 2005: További források Szabó Imre szombathelyi botanikus tanár munkásságának ismeretéhez. (Further sources on the work of the Szombathely botanist and teacher Imre Szabó). Praenorica Folia historico-naturalia 8: 5-28.

BoDó S. 2016: A múzeumok története Magyarországon a dualizmus korában. Akadémiai doktori értekezés, Budapesti Történeti Múzeum, 300 pp.

BARINA Z., SOMOGYI G., LACK H. W.2017: World War I as a power for botanical studies. In: BARINA Z. (ed.) 2017: Distribution atlas of vascular plants in Albania, Magyar Természettudományi Múzeum, Budapest, pp. 26-29.

Boros Á. 1947: Szakosztályi Ügyek. Botanikai Közlemények 42: 26-38.

Boros Á. 1958: Moesz Gusztáv emlékezete. Botanikai Közlemények 47(3-4): 223-238.

Boros Á., Bohus G. 1959: Növénytani Szakülések. Botanikai Közlemények 48(1-2): 136-149.

BuCZ Kó K. (szerk.) 1995: 125 éves a Magyar Természettudományi Múzeum Növénytára. Magyar Természettudományi Múzeum, Budapest, 64 pp.

BUdAI J. 1914: Adatok Borsodmegye flórájához. (Beiträge zur Flora des Komitates Borsod). Magyar Botanikai Lapok 13: 312-326.

Cosulich C. 1991: Antonio Smoquina. Liburnia 52(1): 29-30.

CsıKı E. 1907: A vidéki múzeumok természetrajzi gyüjteményeiről. Múzeumi Könyvtári Értesítő 1: 94-96.

Csongor Gy. 1960: A szegedi Móra Ferenc Múzeum herbariuma. (Das Herbarium des Szegeder Móra Ferenc Museums). A Móra Ferenc Múzeum Évkönyve 1958-1959: 197-221.

DAPSY L. 1878: Vetőmagvizsgáló és növényélettani kisérleti állomás Magyar-Óvárott. Természettudományi Közlöny 10(106): 238-239.

Degen Á. 1904: A Ranunculus polyphyllus W. K. Budapest mellett. (Ranunculus polyphyllus W. K. bei Budapest). Magyar Botanikai Lapok 3(6-7): 216-217.

Degen Á. 1905: Deétéri dr. Borbás Vince. (Dr. Vincenz Borbás von Deétér). Magyar Botanikai Lapok 4(8-11): 172-244.

Degen Á. 1906: Alföldi Flatt Károly. (Karl Flatt von Alföld). Magyar Botanikai Lapok 5(2-4): 50-62.

Degen Á. 1907: A Magyar Királyi Állami Vetőmagvizsgáló Állomások. Pallas Részvénytársaság, Budapest, 23 pp. 
Degen Á. 1922: M. kir. állami vetőmagvizsgáló állomás Budapest, II., Kis Rókus-u. 3. (Kgl. Ung. Samenkontrollstation in Budapest). Kisérletügyi Közlemények 25(1-4): 73-80.

DEGEN Á. 1932: Megemlékezés Istvánffi Gyuláról (Gyula von Istvánffi). Botanikai Közlemények 29(1-4): 12-22.

Degen Á. 1936: Flora Velebitica (1. kötet). Verlag der Ungar. Akademia der Wissenschaften, Budapest.

Degen Á. 1937: Flora Velebitica (2. kötet). Verlag der Ungar. Akademia der Wissenschaften, Budapest.

Degen Á. 1938a: Flora Velebitica (3. kötet). Verlag der Ungar. Akademia der Wissenschaften, Budapest.

Degen Á. 1938b: Flora Velebitica (4. kötet). A Magyar Tudományos Akadémia kiadása, Budapest, LXXIX + 99 pp.

Dicenty D. 1922: M. kir. Szőlő- és Borgazdasági Központi Kísérleti Állomás (Ampelológiai Intézet) Budapest, II. ker., Debrői-út 15. szám. (Die Kgl. Ung. Versuchsanstalt für Weinbau und Kellerwirtschaft (Ampelologisches Institut) zu Budapest, II., Debrői-út 15.). Kisérletügyi Közlemények 25(1-4): 111-116.

Egyed Á. 1969: Ki volt Budai József? Korunk 28(12): 1896-1897.

FEHÉR Gy. 1994: A mezőgazdasági kísérletügyi állomások szerepe a dualizmuskori agrárfejlődésben. (Mezőgazdaságtörténeti tanulmányok 9.). Mezőgazdasági Múzeum, Budapest, 196 pp.

FeIgler F. 1907: A Pozsonyi Orvos-Természettudományi Egyesület múzeumának ötvenéves multja. In: Fischer J., Ortvay T., Polikeit K. (szerk.): 1856-1906 Emlékmü. Kiadja a Pozsonyi Orvos-Természettudományi Egyesület fennállásának ötvenedik évfordulója alkalmából. Pozsonyi Orvos-Természettudományi Egyesület, Pozsony, pp. 75-94.

FEJős I. 1965: A Magyar Nemzeti Múzeum története 1848-1944. Folia Archaeologica 17: 285-303. FeKeTE G., Kováts D. 1974: Magyar herbáriumok. 12. A 100 éves Növénytár herbáriumainak története. II. Herbarium Carpato-Pannonicum. Botanikai Közlemények 61(3): 223-228.

Filarszky N. 1902: A növénytani osztály története és jelen állapota. In: A Magyar Nemzeti Múzeum Növénytára, Budapest, Hornyánszky Viktor, pp. 5-20.

Fischer J. 1907: A Pozsonyi Orvos-Természettudományi Egyesület története. In: Fischer J., Ortvay T., Polikeit K. (szerk.): 1856-1906 Emlékmű. Kiadja a Pozsonyi Orvos-Természettudományi Egyesület fennállásának ötvenedik évfordulója alkalmából. Pozsonyi OrvosTermészettudományi Egyesület, Pozsony, pp. 1-74.

FöldVÁRY D. 1911: A Gagea pusilla virágjának biologiája. A kert 17(15): 465-468.

FrA KNóI V. 1908: Visszatekintés a Múzeumok és Könyvtárak Országos Tanácsa és Főfelügyelősége egy évtized munkásságára. Stephaneum Nyomda R. T., Budapest, 17 pp.

FrenYó V. 1993: Paál Árpád halálának 50. évfordulójára. Botanikai Közlemények 80(1): 9-12.

FüHRER E. és Solymos R. 2008: 110 éves az intézményes erdészeti kutatás, erdészeti „kísérletügy”. In: Albert L. et al. (szerk.): Erdészeti felsőoktatás 200 éve. Nyugat-magyarországi Egyetem Erdőmérnöki Kar, Sopron, pp. 209-219.

FüLöp É. M. 2007: A Magyar Mezőgazdasági Múzeum gyüjteményeinek gyarapodása az elmúlt száz esztendőben. A Magyar Mezőgazdasági Múzeum Közleményei 2005-2007: 37-58.

GAs Kó B. 2003: A szegedi múzeum természettudományi részlegének története: I. fejezet A természettudományi gyüjtemény. - Studia Naturalia 3: 13-163.

Gомвосz E. 1936: A magyar botanika története. A magyar flóra kutatói. MTA, Budapest, 636 pp.

Gorka S. 1908: A Magyar Királyi Mezőgazdasági Múzeum. Természettudományi Közlöny 40(468): 453-466. 
GulYÁs P. 1940: Magyar írók élete és munkái - új sorozat, 2. kötet. Magyar Könyvtárosok és Levéltárosok Egyesülete, Budapest, 1272 hasáb.

GuLYÁs P. 1941: Magyar írók élete és munkái - új sorozat, 3. kötet. Magyar Könyvtárosok és Levéltárosok Egyesülete, Budapest, 1272 hasáb.

Gyelnik V. 1931: Ramalinae duae novae e Paraguay. Annales de Cryptogamie exotique (Paris) 4(3-4): 150-152.

GYőRFFY I. (1943): Erdély virágtalan növényei (Cryptogamae) a kutatás jövőtnéző megvilágításában. Az Erdélyi Múzeum-Egyesület kiadása, Kolozsvár, 40 pp.

Horváth E. 1966: Adatok Szabó Imre életrajzához és botanikai munkásságához. (Daten über das Leben und die botanische Tätigkeit von Imre Szabó). Savaria - a Vas megyei Múzeumok Értesítője 3: 71-83.

Husz B. 1938: Dr. Schilberszky Károly emlékezete. (1863-1935) (Karl F. Schilberszky). Botanikai Közlemények 35(1-2): 1-22.

JANKA V. 1880: A Magyar Nemzeti Muzeum Füvészeti Osztályának történetéhez. Természetrajzi Füzetek 4(1-2): 13-16.

JÁnossy A. 1957: Kern Hermann 1876-1957. Növénytermelés 6(1): 1-2.

JANOvszky L. 1895: A Trencsén vármegyei Természettudományi egyesület története 1877-1895. A Trencsén Megyei Természettudományi Egylet évkönyve 17-18: 24-54.

JÁvor Ka S. 1925: Magyar Flóra. Studium, Budapest, 1307 pp.

JÁvor KA S. 1957: Bernátsky Jenő emlékezete (1873-1945). Botanikai Közlemények 47(1-2): 1-3.

JÁvorKa S., CsAPODY V. 1934: A magyar flóra képekben. (Iconographia florae Hungaricae). Természettudományi Társulat, Studium, Budapest, $576 \mathrm{pp}$.

KaNitz Á. 1874: II. Növénytani osztály. Erdélyi Múzeum 1(4): 64-66.

KÁroly R. 1912: A mezőgazdasági kisérletügyi intézmények 1906-1910. évi működése. Kisérletügyi Közlemények 15(Pótfüzet): 1-348.

KÁRPÁTI Z. 1967: Lengyel Géza emlékezete (1884-1965). Botanikai Közlemények 54(3): 117-121.

KÁRPÁTI Z. 1970: Zsák Zoltán emlékezete (1880-1966). (Erinnerung an Zoltán Zsák). Botanikai Közlemények 57(1): 1-7.

KenYeres Á. (szerk.) 1967: Magyar Életrajzi Lexikon 1. kötet, A-K. Akadémiai Kiadó, Budapest, $1040 \mathrm{pp}$.

KeNYeres Á. (szerk.) 1969: Magyar Életrajzi Lexikon 2. kötet, L-Z. Akadémiai Kiadó, Budapest, $1104 \mathrm{pp}$.

KeRÉNYi-NaGY V. 2018: A Magyar Mezőgazdasági Múzeum és Könyvtár Agrobotanikai gyűjteményének kincsei. Botanikai Közlemények 105(2): 286.

Kern H. 1922: M. Kir. Növényélet- és Kórtani Állomás, Budapest II., Debrői-út 17. (Kgl. Ung. Pflanzenphysiologische und Phytopathologische Anstalt zu Budapest, II, Debrői-út 17.) Kisérletügyi Közlemények 25(1-4): 133-140.

KIss L. 2015: Egy „bogaras” doktor - Brancsik Károly (1842-1915), Trencsén vármegye foorvosa. Orvosi Hetilap 156(46): 1875-1877. https://doi.org/10.1556/650.2015.ho2533

Kocs I. 2015: Bibó József (1843-1914) herbáriumi gyüjteménye a Székely Nemzeti Múzeumban. (The Herbarium of József Bibó (1843-1914) from Székely National Museum). Acta Siculica 2014-2015: 39-69.

Kováts S. 1908: A csanádi papnevelde története. 1806-1906. Csanádegyházmegyei Könyvnyomda, Temesvár, 567 pp.

KuHN L. 1878: Társulati ügyek. Természettudományi Füzetek 2(2): 53-57.

LENDL A. 1906: Kis-ázsiai utazásom. Természet 9(21): 241-242. 
LENGYEL G. 1927: Visszapillantás a Szakosztály háromszáz ülésére. Botanikai Közlemények 24(3-4): 82-91.

Lengyel G. 1936: Degen Árpád emlékezete 1866-1934. (Erinnerung an Árpád v. Degen). Botanikai Közlemények 33(1-6): 1-77.

LENGYEL G. 1939: Gerhardt Guido 1876-1939. Kisérletügyi Közlemények 41(1-6): 153-154.

MÁGócsY-DiETz S. 1932: Csíkmádéfalvi Istvánffi Gyula emlékezete. (Zum Gedächtnis Gyula Istvánffi's von Csíkmádéfalva). Botanikai Közlemények 39(1-4): 1-11.

Magyar P. 1961: Dr. Roth Gyula 1873-1961. Az Erdő 10(3): 81-87.

MiH ALı J J. 1915: A Múzeumok és Könyvtárak Orsz. Főfelügyelősége hatáskörébe tartozó közgyüjtemények működése és fejlődése az 1914. évben. Muzeumi és Könyvtári Értesítő 9: 40-131.

Min ALI K J. 1916: A Múzeumok és Könyvtárak Orsz. Föfelügyelösége hatáskörébe tartozó közgyüjtemények működése és fejlődése az 1915. évben. Muzeumi és Könyvtári Értesítő 10: 80-162.

MıнALI K J. 1917: A Múzeumok és Könyvtárak Orsz. Főfelügyelösége hatáskörébe tartozó közgyüjtemények működése és fejlődése az 1916. évben. Muzeumi és Könyvtári Értesítő 11: 142-218.

Moesz G. 1933: Kümmerle Jenő Béla emlékezete. (Zum Gedächtnis Eugen Béla Kümmerle‘s). Botanikai Közlemények 30(1-4): 1-22.

Moesz G. 1941: Thaisz Lajos. In: Förster R. (szerk.): A Kis Akadémia negyvenkét esztendeje az ezredik előadásig 1899-1941. A Kis Akadémia Könyvtára XLII., Budapest. pp. 463-464.

Moesz G. 1943: Filarszky Nándor emlékezete. (Erinnerung am N. Filarszky). Botanikai Közlemények 40(3-4): 147-169.

Nemes L. 1999: Anisits János Dániel emlékére (To the János Dániel Anisits’s memory). Debreceni Pozsgás-Tár 2 (különszám): 2-61.

PAÁl Á. 1926: Linhart György (Georg Linhart). Folia Cryptogamica 1(3): 101-109.

PÁzMÁNy D. 1996: Elhunyt László Kálmán 1900-1996. Clusiana 3: 105-108.

PÉTer M. 1925: Dr. László Ferenc. Pásztortűz 11(20): 422-424.

Pif Kó D. 2018a: Botanikai élet a dualizmus kori Magyarországon (1867-1918). I. A felsőfokú oktatás fejlődése és annak hatása a hazai botanikára. Botanikai Közlemények 105(2): 179-222. https://doi.org/10.17716/botkozlem.2018.105.2.179

PIFKó D. 2018b: Magyar botanikusok határozója a dualizmus utolsó éveiből. Kitaibelia 23(2): 117-132. https://doi.org/10.17542/kit.23.117

Pifkó D., Andrik É., Kohut E., Karácsonyi K., Kish R., Shevera M. 2015: Vágner Lajos (1815-1888) hagyatéka a Magyar Természettudományi Múzeumban (Lajos Vágner's (18151888) scientific heritage in the Hungarian Natural History Museum). Annales historico-naturales Musei nationalis hungarici 107: 239-256.

PriszTER Sz. 1994: Raoul Francé emlékezete (1874-1943). Botanikai Közlemények 81(1): 105-106.

RaPaICs R. 1926: Linhart György emlékezete. Természettudományi Közlöny 58(831): 217-231.

Rотн Gy. 1922: Vadas Jenő (1857-1922). Erdészeti Lapok 61(15-16): 211-216.

Sipos M. 2013: Wlassics Gyula szerepe a magyar könyvtárügyben a századfordulót követő évtizedekben. 1. rész. Könyvtári Figyelő 59(1): 91-114.

Somlyay L. 1997: Szepesfalvy János. In: NAGY F. (szerk.): Magyar Tudóslexikon A-tól Zs-ig. Better Kiadó, Budapest, pp. 768-769.

SomLYAY L. 1999: Növénytan. In: FÁBRY Gy. (szerk.): Magyarország a XX. században 4. kötet. Tudomány 1. Műszaki és természettudományok, Babits Kiadó, Szekszárd, pp. 481-489.

Soó R. 1932: Kritikai megjegyzések és újabb adatok a magyar flóra ismeretéhez V. (Kritische Bemerkungen und neue Beiträge zur Kenntnis der ungarischen Flora V.). Botanikai Közlemények 29(5-6): 122-132. 
Soós G. 1979: Ünnepi megemlékezés Doby Géza professzorról. Agrártudományi Közlemények 38 (1-2): $1-4$.

Soós L. 1988: Az Országos Phylloxera Kísérleti Állomás létrehozása. Agrártörténeti Szemle 30: 339-365.

SURÁNYI B. 1992: Adalék rét- és legelögazdálkodásunk 1867-1945 közötti történetéhez. Agrártörténeti Szemle 34(1-4): 77-118.

SzABó Cs. 2016: Béla Cserni and the beginnings of urban archaeology in Alba Iulia. Editura Mega, Cluj-Napoca, $222 \mathrm{pp}$.

SzABó L. Gy. 2015: A magyar gyógynövénykutatás kiemelkedő alakjai. Visszatekintés a Gyógynövény Kutató Intézet centenáriuma alkalmából. 1. rész. Gyógyszerészet 59: 24-33.

SZINNYEi J. 1893: Magyar írók élete és munkái, 2. kötet. Hornyánszky Viktor könyvkereskedése, Budapest, 1474 hasáb.

SZINNYEI J. 1897: Magyar írók élete és munkái, 5. kötet. Hornyánszky Viktor könyvkereskedése, Budapest, 1468 hasáb.

SZINNYEI J. 1905: Magyar írók élete és munkái, 10. kötet. Hornyánszky Viktor könyvkereskedése, Budapest, 1440 hasáb.

SZINNYEI J. 1908: Magyar írók élete és munkái, 12. kötet. Hornyánszky Viktor könyvkereskedése, Budapest, 1438 hasáb.

SZINNYEI J. 1914: Magyar írók élete és munkái, 14. kötet, Hornyánszky Viktor könyvkereskedése, Budapest, 1958 hasáb.

Szmodits L. 2015: Anno... Neves magyar gyógyszerész évfordulók 2015-ben. Gyógyszerészet 59: 34-38.

Takács A., Süveges K., Ljubka T., Löki V., Lisztes-Szabó Zs., Molnár V. A. 2015: A Debreceni Egyetem Herbáriuma (DE) II.: A „Siroki Zoltán Herbárium” (The Herbarium of Debrecen University (DE) II.: The „Zoltán Siroki Herbarium”). Kitaibelia 20(1): 15-22. Elektronikus melléklet (Electronic Appendix) https://doi.org/10.17542/kit.20.15

TAKÁcs I. 1967: A Magyar Mezőgazdasági Múzeum rövid története. A Magyar Mezőgazdasági Múzeum Füzetei 19: 1-52.

Teleki P., Csiki E. 1926: A Magyar Tudományos Akadémia Balkán-kutatásainak tudományos eredményei 3. Adatok Albánia flórájához. Magyar Tudományos Akadémia, Budapest, 346 pp.

TÉTÉNYi P. (1995): A Gyógynövény Kutató Intézet története (1915-1990) 1. rész. - Gyógyszerészet 39(7): 503-509.

V. Góz G. 1990: A Kolozsvári Gyógynövénykutató Állomás működése a századfordulón. (Das Heilpflanzenforschungsstation in Kolozsvár (Klausenburg - Cluj Napoca) um die Jahrhundertwende). A Magyar Mezőgazdasági Múzeum Közleményei 1988-1989: 185-209.

VERSEGHY K. 1963: A catalogue of the new lichen names described by Ö. Szatala. The Lichenologist 2(2): 178-189. https://doi.org/10.1017/s0024282963000177

Vigh K., BALOGH L. 2009: A szombathelyi Savaria Múzeum Természettudományi Tárának története. (History of the Szombathely Savaria Museum Natural History Department). Savaria - a Vas megyei Múzeumok Értesítője 32(2): 175-265.

Vort K. 1992: A magyar közgyüjteményrendszer történetének vázlata a századfordulótól 1949-ig. I. Magyar Könyvszemle 108(1): 23-43.

WLAssics Gy. 1913: A Múzeumok és Könyvtárak Orsz. Főfelügyelösége hatáskörébe tartozó közgyüjtemények fejlődése az 1912. évben. Muzeumi és Könyvtári Értesítő 7: 132-166.

Zвоray B. 1985: Dr. Weber Dezső (1883-1952). Gyógyszerészet 29: 227-228.

Zólyomi B. 1961: Jávorka Sándor. Magyar Tudomány 68(11): 683-686. 


\title{
An overview of botany in Hungary during the dualistic era (1867-1918) II. Cultural and scientific institutions
}

\author{
D. PIFKÓ \\ Department of Botany, Hungarian Natural History Museum, H-1087 Budapest, \\ Könyves Kálmán krt. 40, Hungary; pifko.daniel@nhmus.hu
}

Accepted: 6 May 2019

Key words: agricultural institution, floristical studies, herbarium, history of botany, museum.

Prior to the dualistic era, among the contemporary cultural institutions, "fulltime" botanist was employed in the Hungarian National Museum only, and scientific institutes dealing with botany did not exist at all in Hungary at that time. In the early period of dualism, the education of botany underwent a remarkable development, and the trend continued then throughout the era. More and more well-trained professionals graduated in the rapidly developing higher education institutions, who started to work as a botanist in the new cultural and scientific institutions established since the 1880s. These scientific institutions developed greatly during the last period of the era, employing 25-30 botanists by the time before the First World War. After the AustroHungarian Compromise, an independent botanical department was established within the Hungarian National Museum employing one botanist in the beginning. By the end of the period, six university graduates were working in the department, which thus become one of the most important Hungarian institutions of flora research.

In the countryside, museums had been founded by local patriotic associations, which also had natural history collections. These museums were placed under state control in 1897, ensuring their long-term survival. Plant collections of many countryside museums were increased and maintained also by local teachers, priests, doctors or other professional amateur botanists, who also played a significant role in the flora inventory of Hungary.

Agricultural, viticultural and forestry research institutes have been established since the $1880 \mathrm{~s}$, primarily accompanying the educational institutions of the capital or of the countryside. In the last two decades of the era, there was a plan to establish a central National Institute of Agriculture and Vine in the capital. Thus, numerous agricultural institutes were moved to Budapest, under the control of the Ampelology Institute, which operated independently of the educational institutions. Agricultural and forestry research institutes were involved in floristic research at various intensities. One of the most important centers was the Seed Testing Station in Budapest led by Árpád Degen. 